\title{
The SAGE Handbook of Interview Research
}

The Complexity of the Craft

Second Edition

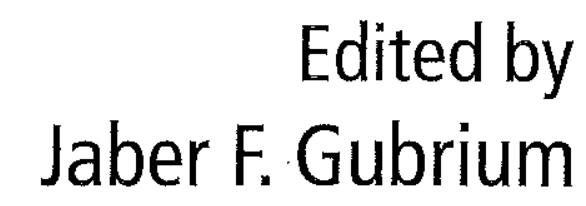

University of Missouri

James A. Holstein

Marquette University

Amir B. Marvasti

Pennsyivania State University, Altoona

Karyn D. McKinney

Pennsylvania State University, Altoona 


\section{(S)AGE}

Los Angeles | London | New Delhi

Singapore | Washington DC

FOR INFORMATION:

SAGE Publications, Inc.

2455 Teller Road

Thousand Oaks, California 91320

E-mail: order@sagepub.com

SAGE Publications Ltd.

1 Oliver's Yard

55 City Road

London ECIY 1SP

United Kingdom

SAGE Publications Indla Pvt. Ltd.

B i/l 1 Mohan Cooperative Industrial Area

Mathura Road, New Dehi 110044

India

SAGE Publications Asla-Pacific Pte. Ltd.

33 Pekin Street \#02-01

Far East Square

Singapore 048763

Acquisitions Editor: Vicki Knight

Associate Editor: Lauren Habib

Editorial Assistant: Kalie Koscielak

Permissions Editor: Adele Hutchinson

Production Editor: Laureen Gleason

Copy Editor: QuADS Prepress (P) Ltd.

Typesetter: C\&M Digitals (P) Ltd.

Proofreader: Scott Oney

indexer: Molly Hall

Cover Designer; Candice Harman

Cover Image: Weber, Max. Tapestry. 1913. Max

Weber. By Alfred Werner. New York: Harry Abrams

Publishers, 1975. 89. Print.

Marketing Manager: Nicole Elliost

Copyright $(\mathcal{C} 2012$ by SAGE Publications, Inc.

All rights reserved. No part of this book may be reproduced or utilized in any form or by any means, electronic or mechanical, including photocopying, recording, or by any information storage and retrieval system, without permission in writing from the publisher.

Printed in the United States of America

\section{Library of Congress Cataloging-in-Publication Data}

The SAGE handbook of interview research : the complexity of the craft / editors, Jaber F. Gubrium ... [et al.]. - 2nd ed.

p. cm.

Rev. ed, of: Handbook of interview research : context \& method / editors, Jaber F. Gubrium, James A. Holstein. c2002.

Includes bibliographical references and index.

ISBN 978-1-4129-8164-4 (cloth)

1. Interviewing-Handbooks, manuals, etc. I. Gubrium, Jaber F. II. Handbook of interview research. III. Title: Handbook of interview research.

$\mathrm{H} 61.28 . \mathrm{H} 362012$

$158.3^{\prime} 9-\mathrm{dc} 23 \quad 2011034825$

This book is printed on acid-free paper.

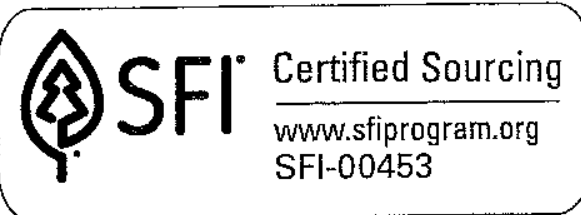

121314151610987654321 


\section{CONTENTS}

Preface

Introduction: The Complexity of the Craft 1

Jaber F. Gubrium, James A. Holstein,

Amir B. Marvasti, and Karyn D. McKinney

\section{PART I. INTERVIEWING IN CONTEXT}

1. The History of the Interview Jennifer Platt

2. Narrative Practice and the Transformation of Interview Subjectivity Jaber F. Gubrium and James A. Holstein

3. Postmodern Trends: Expanding the Horizons of Interviewing Practices and Epistemologies

Michael Ian Borer and Andrea Fontana

4. The Pedagogy of Interviewing

Kathryn Roulston

PART II. METHODS OF INTERVIEWING

5. Survey Interviewing

Royce A. Singleton Jr. and Bruce C. Straits

6. The Interpersonal Dynamics of In-Depth Interviewing Jobn M. Johnson and Timotby Rowlands 
7. The Life Story Interview as a Mutually Equitable Relationship Robert Atkinson

8. Interviewing as Social Interaction Carol A. B. Warren

9. Autoethnography as Feminist Self-Interview Sara L. Crawley

10. Focus Groups and Social Interaction David L. Morgan

11. Internet Interviewing Nalita James and Hugh Busher

12. The Implications of Interview Type and Structure in Mixed-Method Designs

Janice M. Morse

PART III. LOGISTICS OF INTERVIEWING

13. Interview Location and Its Social Meaning Hanna Herzog

14. The Value of Interviewing on Multiple Occasions or Longitudinally Anne Grinyer and Carol Thomas

15. The Interview Question Jinjun Wang and Ying Yan

16. Interview and Sampling: How Many and Whom Ben K. Beitin

17. Culture Work in the Research Interview Shannon K. Carter and Christian L. Bolden

18. After the Interview: What Is Left at the End Christopher A. Faircloth

19. Managing the Interviewer Self Annika Lillrank John B. Talmage

21. Constructing the Respondent Lara J. Foley

22. Five Lenses for the Reflexive Interviewer Linda Finlay 
23. Stigma and the Interview Encounter

Kay E. Cook

PART V. ANALYTIC STRATEGIES

24. Qualitative Interviewing and Grounded Theory Analysis

Kathy Charmaz and Linda Liska Belgrave

25. Analysis of Personal Narratives

Catherine Kobler Riessman

26. Investigating Ruling Relations: Dynamics of Interviewing in Institutional Ethnography

Marjorie L. DeVault and Liza McCoy

27. Interviews as Discourse Data

Pirjo Nikander

28. Using Q Methodology in Qualitative Interviews

David Shemmings and Ingunn T. Ellingsen

29. Using Software to Analyze Qualitative Interviews

Clive Seale and Carol Rivas

PART VI. ETHICS OF THE INTERVIEW

30. Informed Consent

Marco Marzano

457

Karen Kaiser

32. Protecting Participants' Confidentiality Using a Situated Research Ethics Approach

Kristin Heggen and Marilys Guillemin

33. Assessing the Risk of Being Interviewed Anne Ryen

34. Toward Conciliation: Institutional Review Board Practices and Qualitative Interview Research

Michelle Miller-Day

PART VII. CRITICAL REFLECTIONS

35. Stories About Getting Stories: Interactional Dimensions in Folk and Personal Narrative Research

Kirin Narayan and Kenneth M. George

36. Interview as Embodied Communication 
37. The (Extra)Ordinary Practices of Qualitative Interviewing Tim Rapley

38. Eight Challenges for Interview Researchers. Jonathan Potter and Alexa Hepburn

Author Index

571

Subject Index

About the Editors

603

About the Contributors

605 


\section{PREFACE}

$18 \begin{aligned} & \text { s an approach to data collection, inter- } \\ & \text { viewing continues to expand, diver- } \\ & \text { sify, and evolve with the reflexive }\end{aligned}$ revision of long-standing assumptions. Core principles of the traditional model of the structured interview - such as the distinctive roles of the interviewer and the respondent-have been reformulated in a number of ways and across a wide range of disciplines. The first edition of the Handbook of Interview Research successfully delivered the latest developments in the enterprise. This revised edition both builds on and moves beyond the first edition by

- updating the book in terms of recent developments, especially in qualitative interviewing;

- shortening the volume so that it can be used as the main text for graduate seminars in qualitative research as well as a general reference book;

- featuring a how-to/instructional approach through empirically and theoretically informed discussions; and

- enhancing the multidisciplinary flavor of the first edition.

The contributing authors offer a survey of the field, with an emphasis on empirical diversity, procedural options, and theoretical choices. In this edition, three new sections have been added:

- Logistics of Interviewing

- Self and Other in the Interview

- Ethics of the Interview

While there is ample coverage of more traditional interviewing approaches and concerns (see, e.g., the chapters on survey interviews and quantitative analysis), the new edition emphasizes the dynamic, interactional, and reflexive dimensions of the research interview. This is in keeping with newly emerging interests in the field and the editors' expertise in presenting the research interview in this way. The volume highlights the myriad dimensions of complexity that are emerging as researchers increasingly frame the interview as a communicative opportunity as much as a data-gathering format. Like the original volume, the second edition begins with the history and conceptual transformations of the interview. The subsequent chapters are organized around the following main components of interview practice:

- Part I: Interviewing in Context

- Part II: Methods of Interviewing

- Part III: Logistics of Interviewing 
- Part IV: Self and Other in the Interview

- Part V: Analytic Strategies

- Part VI: Ethics of the Interview

- Part VII: Critical Reflections

As indicated by the subtitle of the new edition (The Complexity of the Craft), the research interview is being recast as a complex, multidimensional collection of assumptions and practices. Having shed the presumption that a particular model of interviewing is the "gold standard" of data collection, interviewing's persistent, ubiquitous presence in the social sciences is marked by an amazing diversity. Taken together, the contributions to the Handbook encourage readers simultaneously to learn the frameworks and technologies of interviewing and to reflect on the epistemological foundations of the interview craft. We invite readers to view the chapter contents both as points of emphasis in a common enterprise and as reflexive reconsiderations that have taken an uncommonly imaginative direction.

It goes without saying that the Handbook would not have been possible without the superb work of the contributing authors. We deeply appreciate their scholarly insight, spirit of innovation, generosity, and consummate professionalism in working with us on this volume. We also thank the volume's editorial board and reviewers, who were called on for critical guidance and insight.

Last, but not the least, we are also extremely grateful to all the people in the editorial, production, and marketing departments at SAGE Publications who did so much to bring this project to fruition. 


\section{5 \\ STORIES ABOUT GETTING STORIES \\ Interactional Dimensions in Folk and \\ Personal Narrative Research}

\section{Kirin Narayan and Kenneth M. George}

There is a thirst among the Paxtun women for autobiography. There is also a correct way to "seek the person out" with questions. One day, when my daughter's nanny had observed me eliciting a life story from someone, she later tried to correct me on the grounds that I did not know how to interrogate properly. "You foreigners don't know how to search [latawel] one another," she reproached me. "When we Pakistanis ask a person's story, we don't let a single detail go by. We dig in all the corners, high and low. We seek the person out. That's how we do things. We are storytellers

and story seekers. We know how to draw out a person's heart."

Grima (1991, pp. 81-82)

$\mu$ spread practice, even though the ways of asking and the kinds of stories told may vary. Indeed, most of us are already old experts at coaxing, inviting, or outright demanding stories in our everyday lives. From a child's wheedling, "Tell me," to a friend's bright-eyed prod, "And then what happened?" we regularly make and receive such requests.

Authors' Note: The authors extend their great thanks to Lila Abu-Lughod and Maria Lepowsky for their helpful critiques of an earlier version of this chapter and to the editors of the first and second editions of this Handbook for their insightful comments. 
Pursuing stories within an interview context, though, we bring a set of disciplinary goals and analytic reflections to storytelling transactions. The delights of a well-told tale may continue to sweep us along, but as interviewers we usually elicit and evaluate stories with particular professional agendas. Like Grima's Paxtun critic, the people we seek to interview sometimes already have their own ideas about how one should go about getting stories from others. Storytelling practices-how to tell stories, when and to whom to tell them, how to classify and interpret them, and the broader social, cultural, and political purposes to which stories are put-vary across communities. As stories move about in a range of interpersonal and institutional settings, the presence of a researcher eagerly seeking narrative materials may provide yet another occasion for retellings. In addition to scholars, there are also other specialists with their own purposes and methods for eliciting stories-therapists, shamans, lawyers, doctors, talk show hosts, priests, immigration officers, police, journalists, human rights workers, and so on. This interactive process of extracting and yielding stories plays an ongoing role in the shaping of social life.

Our task in this chapter is to describe the dynamics of interviewing for two sorts of stories: (1) personal narratives and (2) folk narratives. The distinction between them may seem commonsensical at first: personal narratives as person-centered, experiential, and idiosyncratic folk narratives as collective, traditional, and shared. We will, however, argue that such a distinction becomes blurred under closer view and that scholarly insights developed for one category can also illuminate the other. Second, we explore the interactive dynamics of eliciting stories in interviews, emphasizing the need to be aware of the social life of stories that extend beyond the interview. Third, we argue for the importance of supplementing interviews for stories with interviews about stories, to comprehend the interpretive frames that surround storytelling transactions. Finally, we point out the usefulness of critically examining interview transcripts in evolving practice.

Many excellent publications are already available with insights and guidelines for ethnographic or folkloristic interviewing more generally (Atkinson, 1998; Briggs, 1986; Holstein \& Gubrium, 1995; Ives, 1995; Jackson, 1987; Langness \& Frank, 1981; Spradley, 1979). Rather than rehash insights from these other works, we direct interested readers to them. Here, we will draw on a selection of memorable examples of prior interviews for stories, working from the larger ethnographic record and also from our own fieldwork experiences.

\section{Personal and Folk Narratives}

For the better part of the 20th century, most anthropologists, folklorists, and literary specialists assumed that personal narratives are uniquely individual, shaped more by the vagaries of experience than by the conventions of collective tradition. From this vantage, experience appears to dictate the content and form of personal narrative, and so the teller is of central importance. In contrast, folk narratives have been seen as highly conventional, widely shared cultural representations, mediated by the narrative community at large. As Franz Boas (1916) asserted, folk narratives, like myths, "present in a way an autobiography of the tribe" (p. 393). Yet, time and again, the people with whom anthropologists work have not made the same distinction between "personal" and "folk" in terms of the significance of stories to individuals' lives.

Personal stories are also shaped through the use of culturally recognized-and sometimes transculturally negotiated-narrative and linguistic conventions that are themselves differentially put to use by people positioned by gender, age, or class. As life story research in anthropology has shown, such stories are closely tied to cultural conceptions of personhood (Langness \& Frank, 1981). So, for example, when Renato Rosaldo (1976) asked his Ilongot "brother" Tukbaw to speak about his own life, he found that Tukbaw chose to build stories around the wise words and advice of his father rather than provide introspective vignettes about feelings or events. Or when Benedicte Grima went to northwest Pakistan in the hope of researching Paxtun women's romance narratives, she soon learned that the stories the women themselves most liked to tell involved tragic tales of personal suffering, the more tragic the better. A woman who hadn't suffered was assumed not to have a life story. As a 30-year-old unmarried schoolteacher told Grima, "I have no story to tell. I have been through no hardships" (Grima, 1991, p. 84). Similarly, in northwest India, Kirin Narayan was startled when Vidhya Sharma, an educated Kangra village woman, claimed that she had no life story. 
"Look, it's only when something different has happened that a woman has a story to tell," Vidhya said. "If everything just goes on the way it's supposed to, all you can think of is that you ate, drank, slept, served your husband and brought up your children. What's the story in that?" (Narayan, 2004, p. 227). Building on cultural conceptions, individuals may also elaborate their own tastes and convictions about others as appropriate subjects for life story research. Ruth Behar, for example, found that Esperanza, the Mexican peddler whose life story she recorded, followed a narrative structure that moved from suffering to rage to redemption and appeared to expect other women to follow this too. When Behar proposed to ask other women for their life stories, Esperanza objected to her choice of a respected schoolteacher, declaring, "But she, what has she suffered? I never heard that her husband beat her or that she suffered from rages" (Behar, 1993, p. 12).

While the genre that anthropologists have developed to write about people's lives is labeled "life history," we prefer the term life story, or even life stories, to draw attention to the fragmentary and constructed nature of personal narratives (cf. Peacock \& Holland, 1993). Sometimes, asking someone for a "life story" may appear altogether too overwhelming or foreign a request. Asking about particular eras or incidents may do more to stimulate retellings (see also Abu-Lughod, 1993, p. 46). Whether entire life stories or passing anecdotes, personal narratives emerge to serve culturally story-worthy situations and purposes. By looking at the subjects that people choose to dwell on in narrating their lives, we are in a position to see what most matters to them, from their point of view. Describing the hunting stories that Ilongot men of the Philippines love to tell, Rosaldo (1986) observes, "Narrative can provide a particularly rich source of knowledge about the significance people find in their workaday lives. Such narratives often reveal more about what can make life worth living than about how it is routinely lived" (p. 98).

In addition to being implicitly encoded in cultural practice, conventions for talking about lives can also be actively inculcated by institutional demands of various kinds-including the many approaches toward narrative inquiry circulating in scholarly circles (Chase, 2005). Viewing orally told stories among many kinds of "autobiographical acts," Smith and Watson (2001) point to the role of "coaxers, coaches and coercers" in eliciting personal narratives (pp. 50-52; see also Gubrium \& Holstein, 2001; Holstein \& Gubrium, 2000). For example, as Kenneth George (1978) learned in his fieldwork with Pastor John Sherfey, the religious doctrines and practices of evangelical Protestant congregations in the United States lead adherents to routinely "testify" to their spiritual salvation through stories about their personal conversion experience (cf. Harding, 1987, 2001; Titon, 1988; Titon \& George, 1977, 1978). Or as Carole Cain (1991) has argued, Alcoholics Anonymous (AA) teaches newcomers how to tell a confessional story in which they are not just drinkers but alcoholics who have hit rock bottom and need help. Through pamphlets, the examples of others' storytelling, and feedback from fellow participants at AA meetings, people joining the group learn how to shape personal experience along the lines of this key story form. Markets, too, require life stories, especially in establishing literary or artistic reputations or in setting artistic value (cf. Bourdieu, 1993). And we would further add that governmentality always involves shaping citizenship and personal identity around the narrative demands of the nation-state.

Even as personal narratives are shaped by salient storytelling conventions, folk narratives circulating within and across communities are personalized through retellings. If we shift attention from traditional stories to the storytellers, it becomes clear that storytellers put their own creative and aesthetic stamp on folk narratives, personalizing them through retellings to fit particular occasions (Azadovskii, 1974; Degh, 1969). As Swamiji, a Hindu holy man who delighted in making moral and spiritual points through stories, once reflected to Narayan, people told stories according to their own feelings and the feelings of their audience. As Swamiji said,

When you tell a story, you should look at the situation and tell it. Then it turns out well. If you just tell any story any time, it's not really good. You must consider the time and shape the story so it's right. All stories are told for some purpose. (Narayan, 1989, p. 37)

Occasionally, storytellers may make explicit links between their folk narratives and their lives. So, for example, Urmilaji, a woman in the Himalayan foothills, once compared the hard times she had experienced to the wanderings of an exiled king and queen 
in one of the folktales she had told Narayan. In making this explicit connection, Urmilaji was shedding light not just on her own life but on the traditional tale too. When Urmilaji's family priest retold the same story, forefronting the beleaguered king and downplaying the travails of his loyal wife, it became clear that both tellers were recasting the tale according to their own gendered experiences (Narayan, 1997, pp. 121-124; cf. Taggart, 1990).

Reading life histories, one can occasionally witness the subject straining against an anthropologist's conceptions of appropriate "personal" content in an interview. So, for example, when the energetic !Kung woman Nisa suggested to Margery Shostak, "Let's continue our talk about long ago. Let's also talk about the stories that the old people know" (Shostak, 1983, p. 40), it is possible that Nisa was trying to include some of her repertoire of traditional tales within the frame of her life stories. Collecting oral histories, Julie Cruikshank (1990, 1998, 2005) found that the Yukon women elders whose life stories she was recording insisted that their myths were a part of their lives and interspersed retellings of myth with oral histories in ways that directly inspired Cruikshank's scholarship. Similarly, Michael Young (1983) admits in the prologue to Magicians of Manumanua: Living Myth in Kalauna that his book emerged from an attempt to make sense of the ritual expert Iyahalina's puzzling response to a request for his life history:

Instead of telling me tales from his childhood, recounting the circumstances of his marriage, or enumerating his mature achievements, he narrated a sequence of myths and legends that described the activities of his ancestors. He concluded with a passionate peroration on the ritual duties they had bequeathed him, the central task of which was to "sit still" in order to anchor the community in prosperity. (pp. 3-4)

As Young learned, Iyahalina and other hereditary guardians of myths on Goodenough Island identified with the heroes of their myths and drew on mythic themes to construct their own autobiographical narratives. At the same time, possession of these myths was a means of asserting status. In a related vein, Lepowsky (1993, p. 126) found that in Vanatinai, New Guinea, women could also own authoritative versions of myths, a fact that she links to women's stature within this more gender-egalitarian society.
Rather than suppress the disjunction between the kinds of stories we might seek and the stories that we obtain in an interview, interviewers can fruitfully explore this gap between analytic categories and the locally conceived genres that index social power. As the examples just cited show, reflecting on that "gap" can be a source of scholarly insight and creativity (cf. Bauman \& Briggs, 1992; Ben-Amos, 1969/1976; Briggs, 1986).

Even when we receive the sorts of stories we are looking for, the underlying narrative ideology might differ, as both Susan Harding $(1987,2001)$ and Kenneth George (1978) discovered in their respective studies of evangelical Protestant speech in the American South. For the pastors who spoke with Harding and George, the conversations were not "interviews" so much as "testimonies" to the power of God and Christ in their personal lives and in the world more generally. These pastors were also explicit about using the interview testimonies to persuade the interviewers to confess their sins and seek forgiveness and salvation through God in Christ. In this way, the pastors were able to put Harding and George's respective scholarly endeavors to work for their own greater spiritual purpose.

Thus, narratives are not just vehicles for cultural representation; they are also potent tools in social interaction, a form of cultural work. By "cultural work," we mean the ways narrators and audiences use narrative resources for political and social ends. While stories of different kinds certainly contain representations of cultural values, concerns, and patterns, we cannot forget that stories-like all genres of speech-are also practices intended to get things done: to entertain, edify, shock, terrorize, intimidate, heal, comfort, confess, persuade, divulge, and more. Narrative form, then, does not only conjure up other worlds, whether imagined or remembered, but it is also a way to use words for social and political purposes in the immediacies of this world.

\section{$\checkmark$ Getting Stories}

A researcher should always be alert to the ways stories are narrated as part of ongoing social life and to the commentaries, debates, revisions, and retellings they evoke. Yet researchers are not always so lucky as to be in the right place at the right time to participate 
in the many varied moments when people tell or comment on stories that circulate in everyday life. When researchers do have a chance to listen in, their very presence cannot help but shape different aspects of the storytelling occasion; even "conversationally shared stories" (see also Prasad, 2007) can be subtly transformed by the presence of a recording device. Furthermore, a single narrative performance is usually not enough to gain insight into the larger ongoing life of stories and storytelling encounters. Interviews, then, are a useful supplement to the ethnographer's taking part in social life in an engaged, observant way.

Because all storytelling events are situationally unique, narratives heard or exchanged in interviews should not be carelessly confused with or substituted for narratives that take place outside the interview context. All stories emerging from an interview will bear the mark of an interviewer's presence and goals and the hierarchical dynamics of the interview situation. Yet we should not dismiss interview narratives as artificial or contrived. Rather, like so many other social encounters, interviews are culturally negotiated events worthy of analysis (see Briggs, 1986). Since the interview can be an invitation to narrate, it is a wonderful opportunity to grasp-or to at least begin to think about-the complexity of stories exchanged elsewhere in a community.

The word interview has roots in Old French and at one time meant something like "to see one another." While we cannot ignore the social hierarchies of inquiry, we want to underscore how "seeing one another" in interviews requires close attentiveness and an openness to the surprises of dialogue and exchange. How an interview runs its course depends very much on all the participants involved. It is important for the interviewer to be flexible and ready to follow the unexpected paths that emerge in the course of talking together with interviewees. In fact, in our experience, interviews often end up having less to do with structured questions or answers than with the animated exchange of stories. A willingness to reveal one's own stories can also add depth to an interview, inspiring the person one is interviewing to open up.

The ethnographic interview is a bid on the part of a researcher to get a subject to converse openly about a set of issues of concern to the researcher. The political conditions surrounding the consent and participation of interviewees in ethnographic interviews-and in the negotiated elicitation of stories-have been anticipated in human subject protocols designed to hold in check the potentially coercive impulses of social scientific and humanistic inquiry. Setting up an interview becomes an invitation to narrate, albeit one that can be refused, subverted, or turned back on the interviewer.

Seeking stories through interview soon reveals a range of storytelling styles. Some people are energetic raconteurs who will use the interview as a welcome occasion to spin stories. Stories may pour toward the researcher in such dizzying numbers that all he or she needs to do is show engagement with nods or murmurs. In the presence of such practiced storytellers, an interviewer may have to struggle to redirect the stories toward subjects suited to his or her specific interests. Sometimes, the interviewer may need to clarify details. But mostly, when a storyteller takes charge, an interviewer's work is to listen with attentive care so as to formulate necessary questions when the retelling is over.

In other cases, an interviewer has to work harder. It may take a while to formulate the right questions that inspire the telling of stories. Questions that can be answered by a simple "yes" or "no" are particular hazards that give an interviewer a sense of getting nowhere at all. Sometimes, a person is more willing to tell stories outside the formal context of an interview, without recording devices or notebooks at hand. Occasionally, a person being interviewed is willing to tell stories about some things but not others. Here, for example, is a moment from Narayan's (KN) fieldwork in the Northwest Himalayan foothills, when Suman Kumari (SK), a woman who had been animatedly telling stories about her grandmother's and mother's difficult lives, seemed to lose narrative direction when it came to recounting her own life trajectory.

$\mathrm{KN}$ : And after that?

SK: After that what can I say? What can I say, Bahenji? (she turns to her half sister, who along with the mother, is listening in). After that-that's all: sons and all that, and daughters-in-law.

$\mathrm{KN}$ : (seeing that SK is still speaking from the perspective of her mother, tries to turn the interview to SKs own life) And your earliest memories were of this place? What was your childhood like? 
SK: (looking at her sister again) What should I tell her about my childhood, Bahenji?

Sister: That you went to school in your childhood-that's just fine.

[Both sisters laugh.]

SK: What happened is that we went to school, we ate food. Sometimes there would be mangoes on the trees and we'd eat a lot. In the house, she (indicating her mother) would say, "Go to sleep." But as soon as she was asleep, then all three of us would run out!

In a cursory way, Suman Kumari gestured toward memories of school, food, mangos, and naps, yet her own life clearly did not have as much interest to her as tales of her female ancestors. Though Narayan tried to refuel the narrative with questions, these reminiscences soon sputtered to a halt.

Asking people to specify can sometimes be helpful. For example, if someone says, "Life was hard," asking for the ways that life was hard, or if there are any particular moments that stand out as being especially hard, can result in the unpacking of stories. However, the more an interviewer works at extracting a story, the less sure one can be whether this is a story already present in a person's repertoire or whether it has been created only by the interview. This is one of the reasons why including the questions that a researcher asks in the final published work can be crucial to showing how the materials emerged as part of a dialogical process (Dwyer, 1982; Mintz, 1960/1974).

In addition, it's useful to reflect on the structural relations between the interviewer and interviewee, and an interviewee's own reasons for sharing stories. For example, preparing to be interviewed by Barbara Myerhoff in Venice Beach, California, the elderly retired tailor Shmuel Goldman wrote out memories in Yiddish from his childhood in the Jewish quarter of a Polish town; he read these to her in English and elaborated with oral stories. Later, he mused,

For myself, growing old would be altogether a different thing if that little town was there still. . . But when I come back from these stories and remember the way they lived is gone forever, wiped out like you would erase a line of writing, then it means another thing altogether for me to accept leaving this life. If my life goes now, it means nothing. But if my life goes, with my memories, and all that is lost, that is something else to bear. (Myerhoff, 1978, p. 74)

Shmuel sent Myerhoff home with what he called "all this package of stories"; a day later, he died in his sleep. Shmuel's words remind us that sometimes interviews are of value to not just scholars. Transmitting memories to an eager audience, ensuring the survival of stories beyond a limited lifetime, an interviewee may also have a stake in the process.

The elicitation of stories in interviews may be subject to wider constraints around narrative practice. Examples abound in many Native American communities, where storytelling is often intimately linked to seasons, especially winter. To tell or elicit stories at other times can be complicated. So, for example, if a storyteller among the Anishanaabe (Ojibwa) wishes to tell myths outside the winter months, he or she can put on a white weasel pelt, as though simulating snow. Exploring indigenous sacred traditions in the highlands of South Sulawesi, Indonesia, George (1996) had to adjust his interview work to fit with taboos that regulated the time and place for narrative activity: During the long months that stretched from the time of preparing rice fields to the time of harvest, community-wide prohibitions against storytelling and singing were in place, and so he could neither gather nor discuss narrative materials. Once the postharvest ritual season of about 2 months began, he was at liberty to record and discuss traditional songs and stories. Even then, certain taboos remained in effect. For example, sumengo-a genre of ritual song associated with headhunting narrativescould only be performed and discussed for 1 week of the year in any given community. As a result, George had to adjust his research, moving from community to community as sets of taboos came into effect in one yet were relaxed in another.

The kinds of stories appropriate to tell may vary not just with calendrical cycles but also with social location. Gender and age are particularly important factors to consider. For example, adult males in many of Southeast Asia's upland communities especially favor personal stories about going on journeys (see, e.g., George, 1996; Rosaldo, 1976; Steedly, 1993; Tsing, 1993). Interestingly, many of the mythic and historical narratives in these regions feature male "culture heroes" whose journeys lead to the foundation of the communities in question. 
Thus, men's contemporary tales of personal journeys resonate well with the foundational narratives of any specific locale. Women in these same communities have less to say about personal journeys but comparatively more when it comes to talking about trance experience (George, 1993; Steedly, 1993; Tsing, 1993). While both men and women in these communities go on journeys and go into trance, in an important sense it is more relevantly male to make a story of personal travel and more relevantly female to talk about trance experience. The very familiarity and pervasiveness of this pattern makes it all the more striking when, for example, a woman recounts the dangers of a journey she has made. Her move into a typically "male" narrative terrain, then, is an exceptionally revealing and socially salient example of gender play and transgression.

Storytelling forms are not static. Like other genres, different kinds of stories evolve within the play of power in ongoing social life and in dialogue with other genres (Bauman \& Briggs, 1992). This means that there may be shifts in the kinds of stories that are appropriate for different social groups to tell. In his long-term research among the Kwaio of the Solomon Islands, Roger Keesing (1985) at first found men ready to talk about their lives, while women "were fragmented and brief, distancing themselves from serious autobiography with reciprocal jests” (p. 29). On return visits, he found that men's efforts to codify cultural rules and conventions, or kastom, as a form of postcolonial resistance to outside influences had also inspired women to think of culture as an objectifiable "thing" and to lay claim to their own accounts of kastom in which women's importance was given its due. When Kwaio women finally spoke out, they were doing so in counterpoint to the men who had previously been working with Keesing (1985) to codify kastom; also, senior women recounted their lives "as moral texts, as exemplifications of the trials, responsibilities, virtues and tragedies of A Woman's Life" (p. 33). Speaking out, for Kwaio women, was a bid to power. While acknowledging the wider historical shifts that made women perceive their life stories as valuable texts to transact, Keesing also mentions the importance of what he terms "the politics of the elicitation situation" (p. 37) -that is, the particular interpersonal circumstances of the interview. That he was joined by a female fieldworker during the time when he was able to finally record women's stories was also a key factor in coaxing Kwaio women, who had previously been silent about their lives, into animated speaking subjects.

For folklorists, there is an implicit understanding that any retelling is a version rather than the story. There is no urtext, no abstract cultural schema, no basically basic story or structure behind these narrations; there is instead an ongoing history of narratives and retellings that is recalled and put to use in the present (George, 1996, p. 14; cf. McGann, 1991; Smith, 1981). To track the wider life of stories and their constituent parts beyond particular iterations, folklorists have developed tools such as taletype indexes and motif indexes. At the same time, attention to performance has shown how stories emerge within the parameters of particular contexts rather than as perfect forms that float above social life. Such attention to the surfacing of versions in performance can be applied to life histories. So, for example, Laurel Kendall was able to record multiple versions of the stories that Yongsu's mother, a Korean shaman, dramatically retold to Kendall, neighbors, and clients to make varied points about gender, the power of gods, the dangers of lapses in ritual, and so on (Kendall, 1988). George (1978; Titon \& George, 1978) did much the same thing in his study of conversion narratives. He recorded Pastor John Sherfey retelling the story of his conversion nine times-three times in the context of interviews (which Sherfey regarded as testimonies) and six times in the context of preaching and chanting of improvised sermons. The differences between the versions reflected Sherfey's pragmatic rhetorical strategies for each situation, from conversations with relative strangers to sermons before a familiar audience of weekly churchgoers and to the sinners attending a tent revival.

We also would suggest that moving beyond one life story to compare several related life stories may bring narrative forms and their transgressions into clearer focus. This method of juxtaposing life stories was pioneered by Oscar Lewis (1961) in his work with a poor Mexican family, where each family member recounted his or her own stories, revealing multifaceted, cross-cutting, and even diverging perspectives on the same episodes. This method has also been used in other life histories (see Mintz 1960/1974; Viramma \& Racine, 1997) to reveal how positioned perspectives and gendered conventions pervade the shaping of life stories. 
To summarize, then, we would like to emphasize the value of eliciting several versions of folktales and life stories-from the same person through time, and from different people-so that one can see how the uniqueness of a particular telling emerges within larger patterns. Collecting multiple versions of folk narratives and life stories and talking to different storytellers is vital to understanding how narrative traditions are creatively reworked by particular tellers for particular social ends. Also, situating the performance of different versions within social interactions reveals the role of storytelling in the exercise of power, authority, and identity.

\section{$\checkmark$ Interviews About Stories}

Getting a story during an interview still leaves unfinished the intellectual work of making sense of the story. Engaging interviewees in the interpretive process carries great rewards not only for comprehending the meanings, motives, and contexts within and around stories but also for better understanding how interviewees themselves assess the project of interviewing.

For folklore scholarship, Alan Dundes (1966) termed the move beyond eliciting texts to also comprehending indigenous meanings "oral literary criticism." Affirming the theoretical and methodological value of this method, Narayan (1995) also argued for eliciting generalized commentaries on a genre of folklore to supplement talk about particular texts. So if people might find it too revealing to explain why they tell a particular story, one can elicit valuable insights by asking about why people more generally tell stories and what kinds of meanings certain sorts of stories might carry.

Narayan (1997) sought to put this method to work through a collaboration with "Urmilaji" (Urmila Devi Sood), the wise woman we met earlier. After hearing Urmilaji's tales, Narayan transcribed them, thought about them, and came back to talk more-about texts in particular and what meanings they held and about storytelling in general. Sometimes her questions mystified Urmilaji, and at other times, Urmilaji expounded implicit meanings in the tales, self-evident to most Kangra people but perplexing to Narayan: for example, that characters so often, at the end of stories, dropped dead from shame because exposure had compromised their honor. Speaking with Urmilaji about her stories, Narayan also came to understand how stories can be associated with particular prior tellers, keeping their wisdom and influence alive. Urmilaji, for example, loved many of these tales because they had been gifts, lovingly imparted, by her father and aunt-in-law.

Talking to people about stories is a chance to learn how the stories work interpersonally and psychologically. Keith Basso has explored how, among the Western Apache, historical tales bearing moral points are associated with various sites in the landscape. A place called "Trail Goes Down Between Two Hills," for example, is associated with a story about lascivious Old Man Owl and how he was tricked by two beautiful girls; telling this story might comment on how someone's behavior involves uncurbed appetites and so is laughable and offensive (Basso, 1996, pp. 113-120). By telling a story instead of speaking directly, a critique is implied rather than directly stated. The moral points carried within stories become embodied within the geographical landscape, reminding people of occasions when places have been pointed out to them. As Nick Thompson, a spirited elderly Apache, explained to Basso (1996), stories "go to work on your mind and make you think about your life" (p. 58). Using the metaphor of hunting for the aiming of stories at an appropriate quarry, Thompson went on to describe how, when people acted inappropriately, someone would go hunting for them.

So someone stalks you and tells a story about what happened long ago. It doesn't matter if other people are around-you're going to know that he's aiming that story at you. All of a sudden it hits you! It's like an arrow, they say. Sometimes it just bounces off-it's too soft and you don't think about anything. But when it's strong it goes in deep and starts working on your mind right away. No one says anything to you, only that story is all, but now you know that people have been watching you and talking about you. They don't like how you've been acting. So you have to think about your life. (pp. 58-59)

The messages, then, are reinforced by place: "You're going to see the place where it happened, maybe every day if it's nearby. ... If you don't see it, you're going to hear its name and see it in your mind" (Basso, 1996, p. 59). Even when the original 
storytellers die, places continue to stalk the person, reminding him or her how to live right. In this conception of storytelling, then, a good story pierces deep and transforms a person from inside even while its effects are continually reinforced by the outer landscape.

In some societies, much of the power of stories lies in internalizing and embodying them-a "living myth," as Young (1983) memorably puts it. Thus, inviting someone to stand aside to extract explicit meaning, without a cultural frame of reference, may indeed be annoying. As Elsie Mather, a Yup'ik teacher, forcefully wrote to Phyllis Morrow (1995) when the question of explication came up in the course of their collaboration in documenting Yup'ik oral traditions,

Why do people want to reduce traditional stories to information, to some function? Isn't it enough that we hear and read them? They cause us to wonder about things, and sometimes they touch us briefly along the way, or we connect the information or idea into something we are doing at the moment. This is what the old people say a lot. They tell us to listen even when we don't understand, that later on we will make some meaning or that something that we had listened to before will touch us in some way. Understanding and knowing occur over one's lifetime. ...

Why would I want to spoil the repetition and telling of stories with questions? Why would I want to know what they mean? (p. 33)

Like Nick Thompson, Morrow reminds us how stories live in ongoing reverberations through lived practices, not just in analytic reflection. Asking people for meaning isolated from particular contexts of retelling or remembering may appear to fix meaning in inappropriate ways. As Margaret Mills (1991) found in her research in Afghanistan, storytellers may actually thrive on the ambiguity of storytelling and the intertextual relations between stories, as it allows them to make sly commentaries on the sociopolitical world beyond the stories.

The analytic stance that breaks up stories may be perceived as dangerous for other reasons too. In a dramatic example of the dangers of researching stories without being cognizant of their social role or power, Barre Toelken has traced different moments of "enlightenment" in his long-term research on
Navajo Coyote tales. With growing understanding of these Coyote tales, he was told that these were not just entertainment for winter months but were also used in Navajo healing ceremonies. When Toelken discussed the use of these tales with an elderly Navajo singer one night, the singer asked, "Are you ready to lose someone in your family?" Baffled, Toelken asked him to explain. This was the cost of taking up witchcraft, the singer told him. Toelken had been unaware that because of the sorts of questions he asked, he was thought to have an interest in witchcraft, with potentially malevolent repercussions for everyone around him. As Toelken (1996) writes,

For just as the tales themselves in their narration are normally used to create a harmonious world in which to live, and just as elliptical references to the tales can be used within rituals to clarify and enhance the healing processes, so the tales can be dismembered and used outside the proper ritual arena by witches to promote disharmony and to thwart the healing processes. In discussing parts and motifs separately, by dealing with them as interesting ideas which might lead me to discoveries of my own, I had been doing something like taking all the powerful medicines to be found in all the doctors' offices in the land and dumping them by the bucketload out of a low-flying chopper over downtown Los Angeles. (p. 11)

Asking for help with interpretations, then, is like walking a razor's edge: By asking, one runs the danger of making severe cultural faux pas, like Toelken, while by not asking, one risks attributing one's own interpretative frames to subjects. The same dangers hold for both folk narrative and personal narrative, though with personal narrative people may be even more sensitive to interpretations made without consulting them.

A powerful example of the conflict that can arise when informants do not share the interpretations with their interviewers is described in an essay by Katherine Borland (1991). Borland interviewed her grandmother Beatrice Hanson about events that had taken place in 1944, when Beatrice attended a horse race and bet against the wishes of her father. Borland then wrote a student essay in which she interpreted her grandmother's actions as enacting a female struggle for autonomy and, thus, as being feminist. Yet her grandmother, after reading the essay, wrote a 
14-page letter in which she pointedly objected to her feminist granddaughter's interpretation:

So your interpretation of the story as a female struggle for autonomy within a hostile male environment is entirely YOUR interpretation. You've read into the story what you wished to-what pleases YOU. That it was never-by any wildest stretch of the imagination-the concern of the originator of the story makes such an interpretation a definite and complete distortion, and in this respect I question its authenticity. The story is no longer MY story at all. The skeleton remains, but it has become your story. Right? How far is it permissible to go in the name of folklore [or scholarship generally] and still be honest in respect to the original narrative? (Borland, 1991)

This disagreement resulted in a dialogue where both grandmother and granddaughter explained the assumptions they were working from and the different associations they brought to the term feminist. In the process of this conflict and the ensuing discussion, each woman stretched to understand the other's position, and each was educated in the process.

Indeed, feminist work on life stories has been at the forefront of exploring issues of possible reciprocity amid the hierarchical imbalances of interviews and their outcomes (cf. Gluck \& Patai, 1991; Personal Narratives Group, 1989). The sociologist Ann Oakley (1981), for example, long ago advocated replacing a distanced interviewing technique that seeks to deflect questions aimed at the interviewer with "a different role, that could be termed 'no intimacy without reciprocity,"' especially for indepth interviewing through time. She writes, "This involves being sensitive not only to those questions that are asked (by either party) but to those that are not asked. The interviewee's definition of the interview is important” (p. 49). Elaine Lawless (1991) has worked out a system of "reciprocal ethnography" when eliciting the life stories of Pentecostal women ministers: Even as she sought to interpret their personal narratives, she allowed the women ministers to critique and reflect on her ethnographic practices. Such openness to the perspectives of the people interviewed can radically reframe the scholarly project, enhancing accountability to the contradictions and inequalities of the real world.

\section{The Lives of Interviews: Further Reflections}

Before bringing this chapter to a close, we want to remind readers that interviews take place in the daily flow of life. Although some issues and methodologies may call for structured, formal interviews that take interview subjects momentarily away from their everyday circumstances, most of what we learn as ethnographers takes place in the intersubjective flow of what Renato Rosaldo (1989) calls “observant participation." This includes interviews that, in our experience, unfold as brief informal exchanges embedded in long conversations, the routines of daily life, and the deepening bonds of collaborative friendships.

Kenneth George began working with the Indonesian painter Abdul Djalil Pirous in 1994 to study the rise of Islamic art and culture in that country. In their first months together, they would sit down for "interview" evenings-usually with Pirous's wife or children listening in-to record the artist's stories of his life and career up to that time. These storytelling sessions became a bond between them, such that Pirous invited George to help him with his 2002 retrospective show at Jakarta's National Gallery and to write his biography for the event. Working shoulder to shoulder with the artist gave George many occasions to ask about Pirous's signature Qur'anic paintings, paintings that the artist calls his "spiritual notes" (catatan spiritual). For example, George recounts a conversation as he helped Pirous move a particular Qur'anic painting he had just completed for a client:

As we eased the ungainly painting off the work table, around a cabinet, and into another room, I asked how he came up with the verse for the painting. The client, Pirous began to explain, had come to him the year before saying, "Pirous, you are like a father to me. I want a painting with a lesson in it. I will hang it somewhere in my house where it will keep me company when I am old." So Pirous had the burden of selecting a passage from the Qur'an that would speak to the client. We leaned the canvas against a pillar, and then my friend took out an Indonesian edition of the Qur'an to read to me the verses featured in the painting. They were from QS 17, Bani Isra'il, 
verses $35-7 . \ldots$ The passages were an admonition to the client. "It is a reminder to seek knowledge (berilmu), do good deeds (beramal), and to be humble (merunduk)," [said Pirous], "If he doesn't like it and doesn't want it, that's okay, so what? I will keep it, I like it a lot."

We stepped back and, standing side by side, looked over the painting some more. "So, do you think he'll like it?" I asked after a few moments. Pirous turned to me, shrugging. "You know, you grasp a painting as a whole," he replied, "In a single moment you either like it or you don't. It doesn't need time. But for the verse here, you need time for that, for reflection. That's why I say there is aesthetic pleasure and ethical fulfillment in my paintings.” (George, 2010, pp. 99-100)

In a sense, George's long-standing friendship with the artist is an ongoing "interview" or "conversation" through which he learns not just about Qur'anic verse but about ways in which stories help turn paintings into meaningful and companionable objects.

In that same project, George also compared his interview materials about Pirous's first exploration of Qur'anic art in 1971 with published interviews the artist had granted to art historians, journalists, and others scholars. Scouring through newspapers, exhibit brochures, and clippings, George did not come across a public account of Pirous's "conversion" to Islamic aesthetics published before 1985. By the early 1990s, it is a polished and well-rehearsed story. This suggests that it took over a decade for the story to take settled form as part of the artist's broader life story and career history. Although the story earns a place in George's research, it is also fundamental to the art market's need for publicity and painterly reputations.

Narayan's interest in the ways folk narrative and personal narrative interweave led her toward family stories. For years, she has written down or taped key versions of family stories from her Indian relatives: informal interviews that serve as an affirmation of shared identity and that she has drawn on both for scholarly essay (Narayan, 2007a) and by implicitly embedding insights on interactional dynamics within a book-length family memoir (Narayan, 2007b).

We have found that a lot can be learned not just from looking at the work of others but also from looking back at one's own interview practices, whether this involves listening again to tapes or studying transcripts. Most immediately, such a review can help a researcher frame questions about stories already recorded and so more self-consciously engage interviewees in an unfolding interpretive process. More generally, encountering one's own shortcomings can be very instructive for future practice. For example, interviewers may find moments when they have asked questions that elicit "yes" or "no" answers instead of stories, moments when they have interrupted, moments when they have radically misunderstood what someone was trying to say and taken an interview off on a new tangent, and so on. Bruce Jackson (1987) possibly summarizes what many of us feel on transcribing our own tapes when he says, "The most important thing I learned was that I talked too much" (p. 81). Revisiting interviews across time, themes that one might have previously ignored might emerge; Narayan (2009), for example, found on listening again to tapes and looking through notes many years after she had written about a Hindu guru's storytelling as a form of religious teaching that all along he had also been giving her recipes and instructions for cooking.

The mortifying process of looking back at interviews leads one to forgive oneself, to make the best of what has been done, and to look ahead to the next interview or publication. In querying one's own interview practices, it is useful to recall the poet Rilke's (1984) stricture to "Live the questions" (p. 34) rather than expect fixed and certain answers.

\section{$\checkmark$ Conclusions}

The interest in "getting stories" has an institutional backdrop and a place within broader fields of everyday inquiry. As we stated in opening, it is not just scholars who want to obtain stories but the police, medical and psychiatric diagnosticians, journalists, refugee agencies, shamans, social workers, state and corporate bureaucracies, courts, and human rights organizations too. Interview narratives have been put to use not just by anthropologists or folklorists but also by colonizers seeking to comprehend "the native mind," nationalists wanting to mobilize support around an imagined "spirit of the people," and those promoting regional and state articulations of identity.

The distinction between "personal" and "folk" narrative, we have argued, is often blurred in practice, 
and so cross-fertilizing methodologies and theories usually associated with one body of stories or the other may be a source of creative insight. We have emphasized the need to follow other people's own conceptions of stories: as speech genres and as interpersonal, politically charged transactions with a life outside an interview context. Paying attention to the kinds of people who are storytellers, the kinds of stories appropriate to tell with social location, transformations in the kinds of stories told, and the shifting multiplicity of versions enhances appreciation for the specificity of stories that emerge within interviews.

In addition to gathering stories in interviews, we have underscored the value of talking about stories with both the storytellers and listeners. Being sensitive to indigenous conceptions of the meaning and psychological impact of stories can bring our own interpretive biases to light, to be transformed in constructive dialogues. Sometimes, cultural sensitivity may require holding back on analytic questions that carve up stories into constituent elements, cutting them away from the ongoing flow of lived experience.

Finally, we have argued for the ongoing fruits of critically examining interview tapes or transcripts, thus learning to ask and to listen with greater skill. Often, being a good interviewer for stories involves not just asking the right questions but sympathetically listening and holding questions back so that the person being interviewed can shape stories in his or her own way. Equally, being a good interviewer may involve responding to questions from an interviewee and so entering into a reciprocal exchange.

Telling and listening to stories is at the heart of social and cultural life. Much of what we understand as personhood, identity, intimacy, secrecy, experience, belief, history, and common sense turns on the exchange of stories between people. In receiving stories from people, we are often receiving gifts of self. It is incumbent on us to handle these gifts with respect as we pass them onward in our scholarly productions.

\section{$\checkmark$ References}

Abu-Lughod, L. (1993). Writing women's worlds: Bedouin stories. Berkeley: University of California Press.

Atkinson, R. (1998). The life story interview (Sage University Papers Series on Qualitative Research Methods, Vol. 44). Thousand Oaks, CA: Sage.
Azadovskii, M. (1974). A Siberian tale teller (J. Dow, Trans.). Austin: University of Texas Press.

Basso, K. (1996). Wisdom sits in places: Landscape and language among the Western Apache. Albuquerque: University of New Mexico Press.

Bauman, R., \& Briggs, C. L. (1992). Genre, intertextuality and social power. Journal of Linguistic Anthropology, 2, 131-172.

Behar, R. (1993). Translated woman. Boston, MA: Beacon Press.

Ben-Amos, D. (1976). Analytical categories and ethnic genres. In D. Ben-Amos (Ed.), Folklore genres (pp. 215-242). Austin: University of Texas Press. (Original work published 1969)

Boas, F. (1916). Tsimshian mythology (31st Annual Report of the Bureau of American Ethnology). Washington, DC: Smithsonian Institution.

Borland, K. (1991). "That's not what I said": Interpretive conflict in oral narrative research. In S. B. Gluck \& D. Patai (Eds.), Women's words: The feminist practice of oral history (pp. 63-76). New York, NY: Routledge.

Bourdieu, P. (1993). The field of cultural production: Essays on art and literature. New York, NY: Columbia University Press.

Briggs, C. (1986). Learning how to ask: A sociolinguistic appraisal of the role of the interview in social science research. Cambridge, UK: Cambridge University Press.

Cain, C. (1991). Personal stories, identity acquisition and self-understanding in alcoholics anonymous. Ethos, 19, 210-253.

Chase, S. E. (2005). Narrative inquiry: Multiple lenses, approaches, voices. In N. K. Denzin \& Y. S. Lincoln (Eds.), The SAGE handbook of qualitative research (3rd ed., pp. 652-679). Thousand Oaks, CA: Sage.

Cruikshank, J. (with Sidney, A., Smith, K., \& Ned, A.). (1990). Life lived like a story: Life stories of three Yukon native elders. Lincoln: University of Nebraska Press.

Cruikshank, J. (1998). The social life of stories: Narrative and knowledge in the Yukon Territory. Vancouver, British Columbia, Canada: UBC Press.

Cruikshank, J. (2005). Do glaciers listen? Local knowledge, colonial encounters, and social imagination. Seattle: University of Washington Press.

Degh, L. (1969). Folktales and society: Story telling in a Hungarian peasant community (E. M. Schossberger, Trans.). Bloomington: Indiana University Press.

Dundes, A. (1966). Metafolklore and oral literary criticism. The Monist, 60, 505-516.

Dwyer, K. (1982). Moroccan dialogues: Anthropology in question. Baltimore, MD: Johns Hopkins University Press.

George, K. M. (1978). "I still got it": The conversion narrative of John C. Sherfey (Master's thesis). University of North Carolina, Chapel Hill. 
George, K. M. (1993). Music-making, ritual, and gender in a Southeast Asian hill society. Ethnomusicology, 37(1), 1-27.

George, K. M. (1996). Showing signs of violence: The cultural politics of a twentieth-century headhunting ritual. Berkeley: University of California Press.

George, K. M. (2010). Picturing Islam: Art and ethics in a Muslim lifeworld. Malden, MA: Wiley-Blackwell.

Gluck, S. B., \& Patai, D. (Eds.). (1991). Women's words: The feminist practice of oral history. New York, NY: Routledge.

Grima, B. (1991). Suffering in women's performance of Paxto. In A. Appadurai, F. J. Korom, \& M. Mills (Eds.), Gender, genre and power in South Asian expressive traditions (pp. 78-101). Philadelphia: University of Pennsylvania Press.

Gubrium, J. F., \& Holstein, J. A. (Eds.). (2001). Institutional selves: Troubled identities in a postmodern world. New York, NY: Oxford University Press.

Harding, S. (1987). Convicted by the Holy Spirit: The rhetoric of fundamental Baptist conversion. American Ethnologist, 14(1), 167-181.

Harding, S. (2001). The book of Jerry Falwell: Fundamentalist language and politics. Princeton, NJ: Princeton University Press.

Holstein, J. A., \& Gubrium, J. F. (1995). The active interview (Sage University Papers Series on Qualitative Research Methods, Vol. 37). Thousand Oaks, CA: Sage.

Holstein, J. A., \& Gubrium, J. F. (2000). The self we live by: Narrative identity in a postmodern world. New York, NY: Oxford University Press.

Ives, E. D. (1995). The tape recorded interview: A manual for fieldworkers in folklore and oral history (2nd ed.). Knoxville: University of Tennessee Press.

Jackson, B. (1987). Fieldwork. Urbana: University of Illinois Press.

Keesing, R. (1985). Kwaio women speak. American Anthropologist, 87, 27-39.

Kendall, L. (1988). The life and hard times of a Korean shaman: Of tales and the telling of tales. Honolulu: University of Hawaii Press.

Langness, L. L., \& Frank, G. (1981). Lives: An anthropological approach to biography. Novato, CA: Chandler \& Sharp.

Lawless, E. (1991). Women's life stories and reciprocal ethnography as feminist and emergent. Journal of Folklore Research, 29, 35-60.

Lepowsky, M. (1993). Fruit of the motherland: Gender in an egalitarian society. New York, NY: Columbia University Press.

Lewis, O. (1961). The children of Sánchez: Autobiography of a Mexican family. New York, NY: Random House.

McGann, J. J. (1991). The textual condition. Princeton, NJ: Princeton University Press.
Mills, M. (1991). Rhetorics and politics in Afghan traditional storytelling. Philadelphia: University of Pennsylvania Press.

Mintz, S. (1974). Worker in the cane. New York, NY: W. W. Norton. (Original work published 1960)

Morrow, P. (1995). On shaky ground. In P. Morrow \& W. Schneider (Eds.), When our words return: Writing, hearing and remembering oral traditions of Alaska and the Yukon (pp. 27-51). Logan: Utah State University Press.

Myerhoff, B. (1978). Number our days. New York, NY: Simon \& Schuster.

Narayan, K. (1989). Storytellers, saints and scoundrels: Folk narrative in Hindu religious teaching. Philadelphia: University of Pennsylvania Press.

Narayan, K. (1995). The practice of oral literary criticism: Women's songs in Kangra, India. Journal of American Folklore, 108, 243-264.

Narayan, K. (with Sood, U. D.). (1997). Mondays on the dark night of the moon: Himalayan foothill folktales. New York, NY: Oxford University Press.

Narayan, K. (2004). "Honor is honor after all": Silence and speech in the life stories of women in Kangra, northwest India. In D. Arnold \& S. Blackburn (Eds.), Telling lives in India: Biography, autobiography and life history (pp. 227-251). Bloomington: Indiana University Press.

Narayan, K. (2007a). Legends and family folklore. Indian Folklife, 25, 4-7.

Narayan, K. (2007b). My family and other saints. Chicago, IL: University of Chicago Press.

Narayan, K. (2009). Breaking the crust: Reevaluating ethnography across time. Etnofoor: Special Issue on Writing Culture, 21(1), 61-78.

Oakley, A. (1981). Interviewing women: A contradiction in terms. In H. Roberts (Ed.), Doing feminist research (pp. 30-61). London, England: Routledge \& Kegan Paul.

Peacock, J. L., \& Holland, D. C. (1993). The narrated self: Life stories in process. Ethos, 21, 367-383.

Personal Narratives Group. (Eds.). (1989). Interpreting women's lives: Feminist theory and personal narratives. Bloomington: Indiana University Press.

Prasad, L. (2007). Poetics of conduct: Oral narrative and moral being in a South Indian town. New York, NY: Columbia University Press.

Rilke, R. M. (1984). Letters to a young poet (S. Mitchell, Trans.). New York, NY: Random House.

Rosaldo, R. (1976). The story of Tukbaw: “They listen as he orates." In F. Reynolds \& D. Capps (Eds.), The biographical process (pp. 121-151). The Hague, The Netherlands: Mouton.

Rosaldo, R. (1986). Ilongot hunting as story and experience. In V. W. Turner \& E. M. Bruner (Eds.), The anthropology of experience (pp. 97-138). Urbana: University of Illinois Press. 
Rosaldo, R. (1989). Culture and truth: The remaking of social analysis. Boston, MA: Beacon Press.

Shostak, M. (1983). Nisa: The life and words of a !Kung woman. New York, NY: Vintage Books.

Smith, B. H. (1981). Narrative versions, narrative theories. In W. J. T. Mitchell (Ed.), On narrative (pp. 209-232). Chicago, IL: University of Chicago Press.

Smith, S., \& Watson, J. (Eds.). (2001). Reading autobiography: A guide of interpreting life narratives. Minneapolis: University of Minnesota Press.

Spradley, J. P. (1979). The ethnographic interview. New York, NY: Holt, Rinehart \& Winston.

Steedly, M. M. (1993). Hanging without a rope: Narrative experience in colonial and postcolonial Karoland. Princeton, NJ: Princeton University Press.

Taggart, J. M. (1990). Enchanted maidens: Gender relations in Spanish folktales of courtship and marriage. Princeton, NJ: Princeton University Press.
Titon, J. T. (1988). Powerhouse for God: Speech, chant, and song in an Appalachian Baptist Church. Austin: University of Texas Press.

Titon, J. T., \& George, K. M. (1977). Dressed in the armor of god. Alcheringa: Ethnopoetics, 3(2), 10-31.

Titon, J. T., \& George, K. M. (1978). Testimonies. Alcheringa: Ethnopoetics, 4(1), 69-83.

Toelken, B. (1996). From entertainment to realization in Navajo fieldwork. In B. Jackson \& E. D. Ives (Eds.), The word observed: Reflections on the fieldwork process (pp. 1-17). Bloomington: Indiana University Press.

Tsing, A. (1993). In the realm of the diamond queen: Marginality in an out-of-the-way place. Princeton, NJ: Princeton University Press.

Viramma, J. R., \& Racine, J. L. (1997). Viramma: Life of an untouchable. London, England: Verso Books.

Young, M. (1983). Magicians of Manumanua: Living myth in Kalauna. Berkeley: University of California Press. 


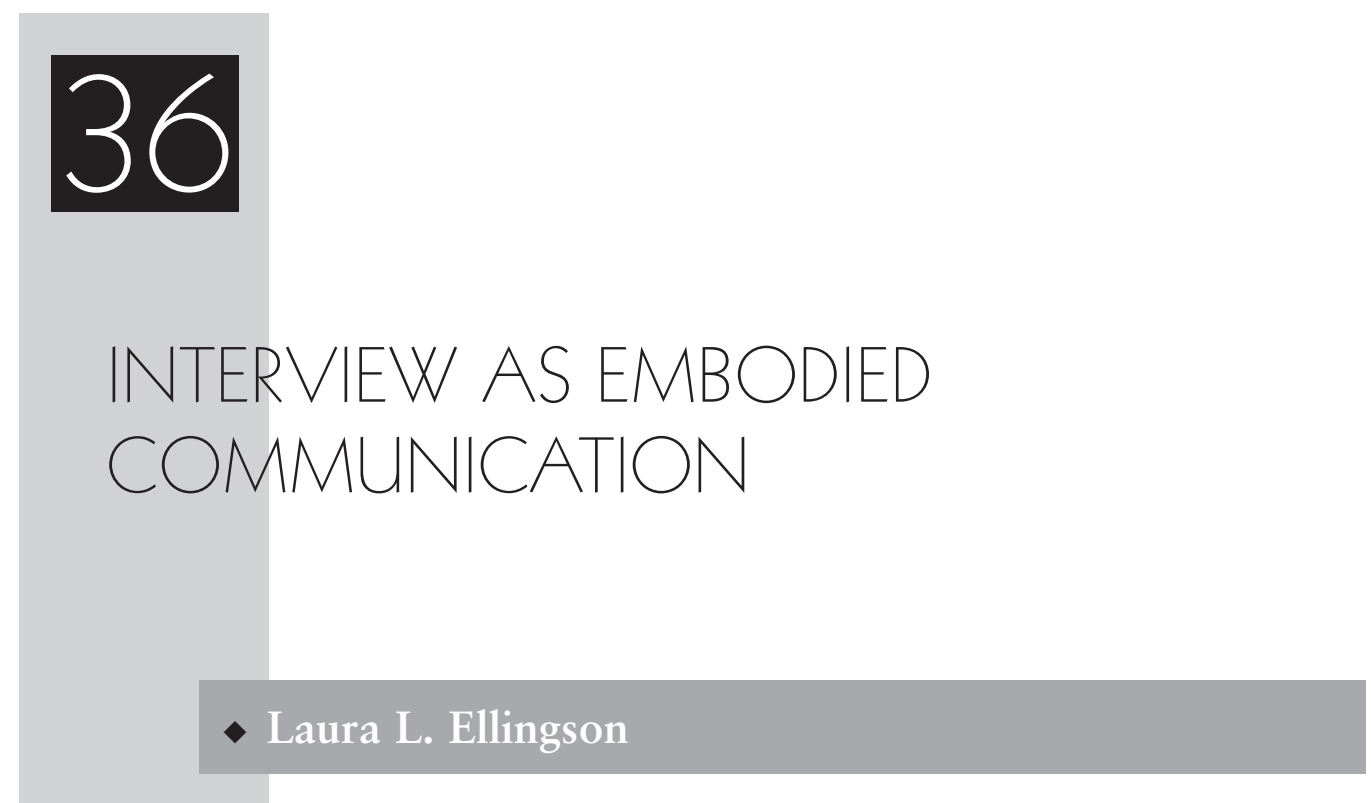

No body, no voice; no voice, no body. That's what I know in my bones.

Mairs (1997, p. 305)

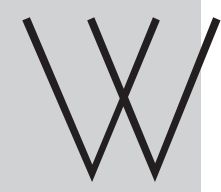

e begin with the body. Although some researchers remain unconscious of it, embodiment is an integral part of the interview process-from preparation, throughout the interview, to data analysis and choices about representation of findings. For example, we select participants for an interview often based on physical characteristics (e.g., race, gender, age) and/or bodily experiences (e.g., living with multiple sclerosis, birthing a baby). In the face-to-face interview, bodies encounter each other as warm, tangible, messy, material manifestations of our selves; bodies do not wait quietly outside the room while our "real" self is interviewed by the disembodied, questioning mind of another. When we analyze interview data, we engage in reflections on how the researcher's embodied experiences are similar to and different from those of our respondents and how that affects meaning making. Even representation is an embodied act. We write or type (or draw, paint, or photograph) and discover new meanings even as we engage in the act of moving fingers across the page or equipment. Interview researchers must reject the mind/body split and embrace our participants and ourselves as whole persons who are bodies, not who have bodies. The body is not a subsidiary of the self but is intricately woven throughout all facets of the self-not deterministically but powerfully.

This chapter explores interview research as an embodied communicative process. Research across the social sciences, education, health sciences, and human services continues to probe important topics and produce valuable findings that have an impact directly on the quality of people's lives. We have the capacity to do tremendous good in the world. I contend that an awareness of and active engagement with issues of embodiment enhance 
our capacity as researchers to design and produce high-quality research and to share our findings widely with practitioners, professional organizations, community members, and scholars across a wide array of disciplines.

This chapter is organized to first explore how the legacy of the mind/body split pervades the socialscientific research enterprise, including, of course, studies based on interview data, followed by the role of embodiment in preparation for and conducting interviews and then during data analysis and representation. Finally, I offer specific suggestions for consciously embodying our research processes and products. I note that my attention throughout this chapter focuses primarily on the dynamics of face-toface interviewing. However, most of the theory, application, and strategies articulated here have relevance to any type of interviewing, including phone interviewing and Internet interviewing.

Before continuing, I also want to take a moment to position myself as the embodied author of this chapter. I write from the position of a midcareer feminist, qualitative researcher with joint academic appointments (and graduate degrees) in the fields of Communication Studies and Women's \& Gender Studies. My two primary areas of study include interdisciplinary teamwork in clinics and communication within extended and chosen family networks, particularly as it relates to aunts' relationships with nieces and nephews. Thus, my body/self has spent a lot of time with (the bodies of) health care workers, patients, and members of extended and chosen families. Feminist theory and methods and a focus on gendered discourse shape my research processes, including the ways in which I prepare for, co-construct, analyze, and represent interview research. Moreover, I am a female body who benefits from white, heterosexual, and middle-class privileges (among others) as they intersect with the marginalization of people with disabilities. I am a cancer survivor with my right leg amputated above the knee, and I rely on a computerized leg prosthesis for daily mobility. My troublesome body demands continual attention and makes it impossible to ignore the ways in which embodiment necessarily affects my research processes, relationships with participants, and perspectives on knowledge construction (Ellingson, 1998, 2005, 2006). Yet my body is not unique in its relevance; all researchers' bodies play important roles in producing interview research.
This chapter illuminates some possibilities for engaging our embodiment to deepen our understanding of the topics we research, the interview processes in which we engage, and the intersections thereof.

\section{The Mind/Body Split and the Erasure of Bodies in Research}

The privileging of the mind over the body is deeply engrained in Western cultures and hence within conventional research methodologies. The mind/body separation posits "a clear division between mind, equated with self, experienced as proactive and unthreatening, and body, experienced as potentially troublesome" (Marshall, 1999, p. 71). Rationality dictates that the (higher) mind-self should seek to control its body-property, preferably to the point of rendering it absent or at least irrelevant. Furthermore, Western cultures traditionally associate "male" or "masculine" with the mind and knowledge production and "female" or "feminine" with the body and the subjectivity of emotion (e.g., du Pre, 2009). Such a mind/body split renders bodily knowledge oxymoronic; indeed, "it is as if 'facts' come out of our heads, and 'fictions' out of our bodies" (Simmonds, 1999, p. 52).

An alternative feminist epistemological perspective bridges and blurs the boundary between the mind and body: "We do not have bodies, we are our bodies" (Trinh, 1999, p. 258). We encounter the world through our bodies and engage in some forms of preconceptual learning through our interactions with others by using our senses-this is literally “sense making” (Barnacle, 2009).

As animals we have bodies connected to the natural world, such that our consciousness and rationality are tied to our bodily orientations and interactions in and with our environment. Our embodiment is central to who we are, to what meaning is, and to our ability to draw rational inferences and to be creative. (Johnson, 1987, p. Xxxviii)

In this epistemology, "instead of the body being positioned as a bar to knowledge, knowledge is produced through the body and embodied ways of being in the world" (Price \& Shildrick, 1999, p. 19). Drawing on Merleau-Ponty's work, Barnacle (2009) 
suggests that we are "body-subjects" whose embodied senses provides the basis for us to learn cultural rules and norms, which we internalize, forming the basis for formal learning: "Not only are formal and embodied knowing integrated but the former is dependent upon the latter" (p. 30). Thus, "any adequate account of meaning and rationality must give a central place to embodied and imaginative structures of understanding by which we grasp our world" (Johnson, 1987, p. xiii).

Furthermore, beliefs about the relationship between the mind and body point to a fundamental tension surrounding what one means when one speaks of "the body." On the one hand, philosophers and scholars construct a notion of the body as a material entity whose potential meanings are constituted and circumscribed by culture(s) through particular discursive systems that privilege certain sets of norms and values (e.g., those of biomedicine, global capitalism, the U.S. prison industrial complex, or religious doctrines) (Gergen, 1994). On the other hand, bodies can also be understood as containing our essential qualities (e.g., emotions, gut instincts, physical characteristics) and material being. That is, cultural meanings certainly vary and have dramatic impact on how we come to interpret bodies, but we cannot completely disassociate such meanings from the concrete, physical reality of the body as a lived entity (e.g., Marshall, 1999).

Moreover, "the body" becomes an impossibility when researchers seriously consider embodiment within knowledge production. Instead, bodies must be taken seriously as multiple, diverse, and situated. Bodies are never neutral but rather are "maps of the relation between power and identity" (Rose, 1999, p. 361) that cannot be separated from the politics of knowledge production (e.g., Davis, 1990). The singular body privileges those bodies on whom the status quo confers the most privilege-white, male, heterosexual, affluent, Western, able-bodied-by generalizing the experiences of the elite as normative and also as the ideal against which nonwhite, female, LGBTQ (lesbian, gay, bisexual, transgender, and queer), poor, Third World, and disabled bodies will inevitably be found wanting (Minow, 1990). Unequal power distribution becomes evident when we consider bodies in interviews, and "we are forced to take account of the ways in which our own bodies and the bodies of our participants are inscribed with power" (Del Busso, 2007, p. 313).
And yet we tend to conduct and represent research as though knowledge were produced without unruly bodies involved. The performance of "disembodied researcher" has been repeated for so long that it functions as a set of naturalized norms that privilege a masculinist rationality as the only legitimate form of knowledge, accorded only to those with sufficient social privilege to deny their feminine unruliness. Leaving (our own and others') bodies unmarked in our reports and other representations is the privilege of the powerful. Research accounts largely reflect social science norms that frame the researcher's personality, body, and other sources of subjectivity as irrelevant. Disembodied prose appears to come from nowhere, implying a disembodied author (Haraway, 1988). Researchers have used the power of academic discourse to define their bodies as essentially irrelevant to the production of knowledge (Denzin, 1997). Hence, when researchers' bodies remain unmarked in our accounts, they reinscribe the power of scholars to speak without reflexive consideration of their positionality. Of course, marginalized body markers cannot be denied by less powerful researcher-bodies who do not have the privilege of disowning their unruly physicality; scholars with queer, disabled, nonwhite, and otherwise marked bodies encounter resistance to their claims of disembodied prose and the privilege of objectivity (e.g., Brown \& Boardman, 2010; Sharma, Reimer-Kirkham, \& Cochrane, 2009; Simmonds, 1999). Likewise, often we render our participants' embodied experiences marginal to our research findings or else unproblematically offer their bodies up as evidence by failing to problematize them at all, thus essentializing bodily markers such as race, gender, or sexual orientation as constitutive of meanings about members of a marginalized group.

At the same time, we must not simply invert the hierarchy to privilege the body to the exclusion of the mind, thus reinforcing the dichotomy between emotional/imaginative and rational logics.

In seeking to re-engage body-mind relations it is important not to lose sight of why the body was considered a problem in the first place, particularly if we are to avoid merely reversing established hierarchies.... [We need] a way of re-thinking body-mind relations that complicates rather than erases demarcation between the two. (Barnacle, 2009, p. 28) 
Cartesian and Kantian reasoning reinforces dichotomies that "have made it extremely difficult to find a place in our views of human meaning and rationality for structures of imagination" that would help us think more holistically about the limits of emotional responses and the misuses of rational logics (Johnson, 1987, p. xxix).

\section{- Embodiment as a Focus of Inquiry}

Feminist and other critical attention to the role of embodiment in research processes has led to and paralleled interest in the varieties of embodiment as a topic of inquiry throughout the social sciences, medical and health fields, social services, and education. That is, researchers explore through interviews (and other methods) people's lived experiences of their bodies and the meanings they engender for themselves and (with) others, in terms of individual and group identity and within specific contexts. Ironically, most of the studies have followed traditional research report-writing conventions, generating texts that are embodied only to the extent that the representative quotes offered as evidence of patterns reference the body (unless it is an autoethnographic exploration of embodiment). That is, rarely is the body represented using evocative, narrative genres or other media (e.g., photographs) that would enhance an embodied representation of an exploration of embodiment. Topics explored include embodiment of whiteness and hegemonic masculinity through alcohol consumption among college-age males (Peralta, 2007); embodiment during childbirth as it reflects, resists, and negotiates between biomedical and natural birth discourses (Walsh, 2010); the paradoxical experience of embodiment by women with physical disabilities as both invisible and yet rendered highly visible (as different) (Zitzelsberger, 2005); the embodiment of prosthetic limbs among "successful" prosthetic users (i.e., those for whom using a prosthesis is part of their daily way of being in the world) (Murray, 2004); the gendered, sexualized, and ethnic embodiment of Latin musicians performing salsa music in a dance club (RománVelázquez, 1999; for a fascinating, broader explanation of the physical and sensory embodiment of music, see Evans, 2010); older women's embodiment, especially as it relates to socioeconomic class (Dumas, Laberge, \& Straka, 2005); beliefs about embodiment and brain stem death among family members making decisions to donate organs of their loved one (Haddow, 2005); the gendered embodiment of male-to-female transsexuals as they engage in "bodywork" to retrain, redecorate, and reshape their bodies (Schrock, Reid, \& Boyd, 2005); the intersection of racial and cultural identities with gendered embodiment among "gender-liminal" (third sex, transgender, and transsexual) people belonging to cultures indigenous to the South Pacific (Roen, 2001); and the gendered nature of marking on bodies through tattoos, piercings, and "self-injury" or "self-cutting" (Inckle, 2007).

Embodiment is thus both a topic of inquiry and a means of framing inquiry. I now turn to embodied practices for interviewing.

\section{$\checkmark$ Embodiment in the Interview}

Interaction creates meaning (Blumer, 1954). The nature of embodied cognition extends to the phenomenology of human interpersonal communication: "Intersubjective interaction is the cognition and affectively charged experience of self and other. Our bodily structure and sensorimotor skills ground our ability to make sense of the other, and vice versa" (Colombetti \& Thompson, 2008, p. 57).

The play of understanding between self and other arises out of an ongoing creative tension between what is familiar and what is unfamiliar, between self and other, between the known and the fresh textures of the unknown, between the existing framework of understanding that one brings, and the new and context-specific "reality that surpasses" such a brought framework (Gadamer, 1989, p. 109) and between general understandings from the past and the different understandings that come by being present to the otherness of "that" as it lives. (Todres, 2008, p. 1570)

Nonverbal signals such as tone of voice, rate of speech, and eye contact are rooted in the body; interviewer and interviewee adjust their communication in the moment in response to those cues. Indeed, research shows that $90 \%$ of meaning is nonverbal and that when verbal and nonverbal signals contradict, people almost always believe the nonverbal (i.e., embodied signals) (Adler \& Towne, 2005). 
Holstein and Gubrium (1995) suggested that researchers consider interviews to be active: that is, activities in which two participants generate meanings within the encounter, through verbal and nonverbal communication, less a data collection than a co-construction. In this way, the active interviewer can be understood to "virtually activat[e] narrative production" (Holstein \& Gubrium, 1995, p. 123) by the interviewee with questions, signals, and so on. This includes the body as two active parties-both with agency-that interact in a site of knowledge construction, not only of information transmission, as is traditionally framed, with respondents as "vessels" from whom researchers obtain answers (see also Holstein \& Gubrium, 2003). An exemplar of a researcher who indicates awareness of the encounter in which meaning is actively generated may be found in Pollock's (1999) interview study of women's birth narratives as she describes one of her participants' embodied affect:

In whispered, halting tones-checking repeatedly to make sure no one overheard our arrangementsshe asked to meet at my house rather than at her own or at some more public place. In her choice of setting and in the distance she maintained once there, Margaret seemed literally to be guarding her stories from intrusion... Margaret sat on the living room chair, at a long arm's reach from the muffins and tea on the coffee table, at once trembling with anxiety and anger and practically daring me to cross the two or three feet between us. I remember especially how she left: she slid past me, out the door. ... Margaret walked down the front path and away, her chin cocked-in embarrassment? indignation? pride?-taking her story with her. (p. 28)

Later, she describes a key moment in the interview: "She inched forward in her seat, leaning toward me-her face so bright now she seemed to have caught a spotlight—and began nervously, then fervently, to tell a third story" (Pollock, 1999, p. 28).

Del Busso (2007) pointed out that bodies communicate, sometimes in ways we do not intend as researchers, as our bodily signifiers-such as bodily grooming and clothing - are interpreted by our participants: "I felt that my body had spoken directly or indirectly to the women who took part in the research in ways that were incompatible with my feminist identity" (p. 311); her participant did not think she "looked" like a feminist because she was "too feminine" in appearance.

A full exploration of mediated interviewing via phone (see Shuy, 2002) or the Internet (see Mann \& Stewart, 2002) is beyond the purview of this chapter. However, it is vital to understand that while interviews may appear to be disembodied by technology, researcher and participant bodies do not disappear or become irrelevant; they remain present and implicated in complex ways. First, bodily signals are inferred: emotions signified with signs such as emoticons, all caps, and punctuation via Internet or facial expressions assumed to align with the tone of voice on a phone call. Second, research suggests that people are assumed to conform to some linguistic stereotypes that are inferred, such as masculine and feminine styles of voice or written language (Colley $\&$ Todd, 2002) and racial structures reproduced online (Lovink, 2005). Finally, very strong and not necessarily accurate impressions of bodies are produced from different combinations of computermediated communication cues (Jacobson, 1999; Tanis \& Postmes, 2003). In addition, as examined further in the section on representation, typing on a computer for e-mail or online chatting is a physical act, one that invokes mental processes that relate to and differ from those that arise from oral storytelling.

In the next section, I will explore the ways in which embodiment plays a critical role in analyses of interview data.

\section{$\checkmark$ Embodiment in Data Analysis}

\section{TRANSCRIPTION}

Researchers typically audiotape and then transcribe in-person interviews. Far from a neutral act of transferring words from a tape to a page as traditionally framed, transcription is an act of translation between two vastly different media. Stripped of most nonverbal interaction cues and with no descriptions of the participants or setting, standard transcriptions of research interviews focus on accurately representing spoken language, placing rhetorical emphasis on the verbal content while ignoring the differences between oral and written speech. Mishler (1991) argued that moving from oral to written speech involves not accurate dictation but translation; just 
as moving ideas from one language to another may make it impossible to express many ideas literally, writing down oral speech renders it a different entity altogether. People do not process oral speech the same way we read it; we encounter and make sense of language in vastly different ways depending on which organs of the body take in the cues. Thus, Mishler critiques accuracy as a naive standard for evaluating transcription; retaining the actual dialogue in written form does not convey the truth of what happened in the (oral) moment. The rhetorical choices inherent in transcription typically erase bodies completely, leaving only words and sometimes series of cryptic marks that reflect conversationanalytic codes intelligible only to those trained in the techniques and not at all equivalent to the nonverbal cues for which they stand.

Indeed, Mishler argues that transcription is part of data analysis, since the decisions we make about how to represent the interactions on the page already frame our desired findings by structuring the discourse on the page in ways that reinforce the assumptions we bring to the research and our anticipated findings. Analysis of words with no attention to bodies leaves out essential aspects of the story: "Methods of reflexivity and analysis that focus solely on participants' verbal accounts cannot fully grasp the conditions through which the resulting knowledge is produced" (Del Busso, 2007, p. 313). Yet bodies lurk in the background of the disembodied transcripts. Transcript excerpts of participants' speech beg an infinite number of questions about, among other things, the setting in which the interaction took place, the appearance of the people and their positions vis-à-vis one another in the room, and the tone of the discussion. Such accounts obviously present only a very partial representation of "what happened," and of course these disembodied accounts do not favor all participants equally.

\section{WORKING DATA WITH THE BODY}

Interviewing involves embodied practices performed by actors occupying specific standpoints within cultures. The researcher's body-where it is positioned, what it looks like, what social groups or classifications it is perceived as belonging to, what experiences it has had, what its daily routines arematters deeply in knowledge formation. Rather than apologizing for subjectivity or simply stating one's "biases," qualitative researchers can endeavor to remain conscious of the ways in which data analysis implicates the body as the site of knowledge production. In the same way that the interaction within the interview occurred between (active) bodies, data analysis occurs by one or more embodied researchers encountering data that also reflect embodied actors and their meanings. Speaking of teaching and learning the skills of critical thinking, Barnacle (2009) argued that our "gut feelings" are not merely metaphorical but crucial sensations intricately involved in sense making:

Being critical, therefore, becomes an aspect of how one lives one's life, and this is not reducible to a specific skill set that can be deployed or withheld at will. A gut, engaged "moodfully" with the world, to borrow from Heidegger, offers a better model for describing such a phenomenon than a conception of mind dominated by a calculating brain. (pp. 31-32)

Thus, if we consider data analysis as one manifestation of critical thinking, it follows that we must employ our guts as consciously as possible and consider those of our participants as we seek to sort through and discern patterns, construct coherent categories and typologies, and otherwise (re)assemble data into new forms. Attending to embodiment requires "a reflexivity that takes into account much more than an acknowledgement of the ways in which we 'affect' the data collected and how our own subject positions are implicated in the analyses produced" and instead requires attention to the data as encompassing meanings tied to a specific interaction in which specific bodies met each other (Burns, 2003 , p. 230). We need to pay attention to gut knowing as we analyze data, and engage in embodied sense making/reasoning.

Knowledge grounded in bodily sensations encompasses uncertainty, ambiguity, and messiness in everyday life; it is inherently and unapologetically subjective, celebrating-rather than glossing overthe complexities of knowledge production. At the same time, researchers best remember that the gut is hardly infallible: "Sensibilities can orient thought in ways not necessarily beneficial and can also limit or truncate one's openness to inquiry" (Barnacle, 2009, p. 32). Moreover, our understanding of emotions and the accompanying physical sensations is subject to cultural "feeling rules" into which we are socialized 
and that we generally invoke without conscious reflection (Hochschild, 1983). Thus, our gut feelings and other bodily sensations arise as we reread and analyze our data-tears, muscle tension, headaches, feeling energetic, smiling, trembling-and give us clues to meanings embedded in our data (themselves a construction of our and our participants' bodies). Such clues are complex and require careful reflection and interpretation.

Miller-Day's (2004) study of relationships among adult daughters, mothers, and grandmothers illustrates not only the added richness of embodied details but also the vital context for meaning that such details render (more) intelligible for readers. Researchers must attend to "how the interviewer's own embodied subjectivity interacts with that of the respondent in the mutual construction of meanings/ bodies" (Burns, 2003, p. 232) to consider the complexities of the meaning making. Describing one of a series of interviews, Miller-Day (2004) expresses awareness of the bodily connection between herself, her participant, and her sense-making processes:

Once, on a cool spring day, Kelly [participant] and I were walking together in downtown Elkwood, heading for a local pub for a late lunch. The sun was bright, but the chill in the air was palpable, so I pulled my sweater closer to my body, and Kelly placed her arm about me to provide additional warmth. As we walked into the pub I felt comforted by her presence and part of my comfort, I assume, was due to the fact that Kelly was the same age as my older sister. I suspect that some aspect of my sense-memory was stimulated by this "sisterly" hug. (p. 52)

Since this is a study of familial relationships, these details are particularly helpful in considering the position from which Miller-Day and her participants made meaning together.

\section{$\checkmark$ Embodiment in Representation}

Conventional reports omit embodiment. Qualitative research reports typically were written following strictly social-scientific or medical conventions, in which the author's agency is obscured via passive voice (e.g., "The data were collected"). Currently, they more commonly employ a sanitized "I," who reports having taken actions without describing any details of the body through which the actions were taken or the embodied being of the participants with whom the researcher acted. In addition, qualitative researchers may now own up to relevant aspects of their identity in brief statements in methods sections or footnotes of journal articles; for example, I note my identity as a cancer survivor in grounded theory analyses of clinical communication because the participants responded to my impaired body with questions and judgments that certainly affected our interactions (e.g., Ellingson, 2003). More commonly, such epistemological and methodological issues are the focus of fascinating essays that are published separately from the authoritative research accounts in spaces devoted to the development of qualitative methodology (e.g., Qualitative Inquiry, the "Piths, Pearls, and Provocations" section of Qualitative Health Research). Despite the narrative turn that has made qualitative research more credible to the social science, education, and health communities and expanded the options for writing conventions (e.g., Denzin \& Lincoln, 2000), research articles, reports, and essays continue to omit details of their authors' embodied being as they relate to research processes and findings. Autoethnographic accounts and some narrative and postmodern ethnography redress these omissions (e.g., Minge, 2007; Ronai, 1992, 1995); however, the vast majority of such accounts find publication in outlets devoted to qualitative and interpretive research, segregated from research reflecting scientific norms and practices that obscure themselves as neutral standards for knowledge promoted in mainstream disciplinary journals (Ellingson, 2009).

Disembodied writing is intertwined not just with academic writing conventions but with language itself. Our bodies cannot be understood apart from our languaging of them. While bodies do of course have material being, that materiality cannot be transparently understood. Instead, the lenses of culture and language variously filter all interpretations. Words do not spring forth from nowhere; we draw language from cultural reference points to construct categories, descriptions, and labels (Wittgenstein, 1953). Hence, meanings of our bodies and those of our research participants are constructed in particular sociohistorical contexts that entail constraints of language resources, including absence of language for some experiences, feelings, and understandings. "When we try to name our bodily experiences, we are always involved in a dialogue" (Marshall, 1999, p. 71). 
We make sense through our bodies and then reach for language to express ideas. "In the passage from the heard, seen, smelled, tasted, and touched to the told and the written, language has taken place" (Trinh, 1999 , p. 263). Once language has taken place, meaning is created, assigned, and even imposed on the body, and we need to acknowledge that our languaging of experience and ideas can be thought of neither as somehow reporting pure bodily experience nor as purely disembodied knowledge. Likewise, audiences always jointly construct meanings with researcher/ authors when they read research reports in other, equally specific sociohistorical contexts. Language conventions also make it difficult to resist the mind/ body spilt that frames the body as the property of the self (Trinh, 1999).

Moreover, writing is done with fingers and arms and eyes: It is an embodied act, not mental conjuring:

I encourage you to think of writing itself as an embodied practice: Come to [your topic] not with your mind and ideas, but with your whole body-your heart and gut and arms.... What people don't realize is that writing is physical. It doesn't have to do with thought alone. It has to do with sight, smell, taste, feeling, with everything being alive and activated.... You are physically engaged with the pen [or keyboard], and your hand, connected to your arm, is pouring out the record of your senses. (Goldberg, 1986, pp. 37, 50)

When we resist the Cartesian mind/body split and embrace writing about our interview research as something we enact with our whole bodies, not just our heads, we more easily recall sensuous details and construct more visceral prose and richer accounts in other media as well (e.g., Ellingson, 2011; Hayward \& Harter, 2010; Quinlan, 2010; Quinlan \& Harter, 2010).

In the remainder of this chapter, I turn my attention to how the body can be more consciously incorporated into research practice.

\section{- Embodying Our Work: Best Practices for Interview Research}

In this section, I offer strategies for engaging embodiment throughout the processes of face-to-face interview research: preparation for the interview, the actual interview, data analysis, and choices about representation.

\section{PREPARATION FOR THE INTERVIEW}

First, I encourage researchers to learn more about embodiment by consulting the many references cited in this chapter (for beginners, I particularly recommend Burns, 2003). Designing a qualitative study involves both intensive preparation of a schedule of questions that address varying aspects of your research topic and openness to working with whatever words, actions, and signals participants offer in the moment. Effective improvisation, Janesick (2011) argues, is possible only when researchers undergo extensive preparation so that their immediate responses in the midst of an interview (or fieldwork, etc.) remain grounded in and guided by what they have learned deeply and internalized—ethical standards (e.g., do no harm), epistemological stances (e.g., social constructionism), political commitments (e.g., feminism), methodological concepts (e.g., rapport), and extant research literature. Reading about, reflecting on, and collegial discussion concerning embodiment will improve researchers' skills for all phases of interview research.

In a related vein, before conducting the first of a series of research interviews, researchers may benefit from reflecting on how their embodied selves relate to the topic and participants. For example, "stretching exercises" (Janesick, 2011); questions for ethical reflection such as those posed by Fine, Weis, Weseen, and Wong (2000); and/or "wondering" questions (Ellingson, 2009) could all be used to help researchers record their own perceptions and reasoning about embodiment. Ideally, one will return to these questions and reconsider them periodically throughout the processes of data collection, analysis, and representation, as an ongoing dialogue that may yield theoretical, pragmatic, or other insights.

Another strategy is to practice awareness of the problems of essentializing participants' body/selves in research design. Research questions for interview studies typically target people based on traits and/or bodily experiences, for example, young, black, single fathers (Coles, 2001) or elderly Iranian immigrants (Hegland, 2009). Practice awareness of what you are doing when you sort bodies into categories and then 
treat those categories of difference as though they are inherent to the body/selves of participants rather than socially constructed. Cultural categories such as gender, age, race, class, sexuality, and disability provide a useful starting point for exploring the impact of people's bodies on the research opportunities and challenges and for questioning taken-for-granted stereotypes, categories, and labels. Strategic essentialism involves acting as though the identity category were real, even though it cannot be fixed or definitively established (Spivak, 1987). But then we may destabilize the very categories we invoked to select participants by inquiring in the interview as to the meaning of these categories for participants. Such identifiers or specific experiences are meaningful; just remember that none of them are essential to who a person is; categories of difference form, crumble, and reform as political winds shift (Minow, 1990).

Researchers also may interrogate the ways in which recruitment was embodied. For example, the willingness of strangers to comply with a request for an interview or the ease with which one obtained access to a private corporation to conduct research interviews with employees may relate (in part) to potential participants' perceptions of the researcher as similar to them and therefore easier to understand and less threatening. Belonging to a different racial group from that of potential participants or being much older or younger than they are may spark feelings of unease that may make it more challenging to recruit participants. On the other hand, demographic differences also may be capitalized on-I once used the similarity of my age to the likely age of grandchildren of senior (over 70 years of age) oncology patients as a basis to begin conversations with seniors (Ellingson, 2005). In addition, women not wanting to go alone to interview male research participants in their homes could lead to sex and gender influences on interview data, and so on. Such factors will influence directly the methods used and the data compiled. Instead of dismissing these as peripheral concerns, they could be brought into a discussion of how research practices reflect, reinscribe, and/or subvert social power structures that shaped and are shaped by our bodies and their signifiers.

Finally, as researchers, we should consider our own performances of self through a "personal front" (Goffman, 1959), including clothing, grooming, and artifacts or objects. This is not to say that we are not entitled to dress or groom ourselves in ways that make us comfortable or that we should perform an "inauthentic" self. However, participants do read our bodies and respond in both typical and unexpected ways. Therefore, we should think carefully about how best to adapt ourselves to the circumstances of the interview, dressing in business attire to interview a CEO, for instance, but a casual outfit for interviewing child care workers (see also Annika Lillrank's chapter, "Managing the Interviewer Self," this volume).

\section{DURING THE INTERVIEW: EMBODIMENT AS A TOOL FOR ENGAGEMENT}

Think with your body. Pay attention to how your body responds to your surroundings and to your participants' emotions, body language and gestures, and proximity. Draw on all your senses. Rather than simply noting what the room looked like, describe the overchilled office building air or the scent of crayons that clings to preschool children or the squishy feel of the shag carpet lining a participant's living room. If you share a meal with a participant, savor the spicy sauce or the deep chocolate dessert with smell, taste, and touch, being present and attentive to bodily sensations as you eat.

Question the body/self understandings of participants, pressing for specific sensations, details, and movements. One strategy for understanding how to question embodiment is using "experiencebased, body-anchored" interviewing techniques (Stelter, 2010).

Experience-based, body-anchored qualitative interviewing can be defined as a specific way of conducting an interview, where the pivotal point is the participant's experiential, embodied involvement in the issues of the research interview.... [Researchers] can use this interview approach to deepen their understanding of how bodily reactions and body anchored experiences are related to thoughts, emotions, and actions. (Stelter, 2010, p. 859)

Ask questions that focus on embodied feelings and sensations as situations or events are recalled and brought to the present moment. Ideally, in this context, both participant and interviewer should seek to be as nonjudgmental as possible, both making a conscious effort not to impose hierarchies of value 
on aspects of the experience described in the interview (Stelter, 2010, pp. 863-864).

Similarly, use sensuous language when making notes during the interview. When documenting the experience of the interview, notes could be embodied using a language that is sensuous and textured: "It is the lived body that connects language to the world of experience. Such sense-making is not just logical and populated by bits of information, but is full of textures," senses, and bodily sensations (Todres, 2008, p. 1570). The richer and more descriptive the account of the interview, the more context is available for interpreting the transcripts later.

Finally, interviewers should be open to personal change as a consequence of encountering the embodied selves of participants.

When researchers recognize the encounter as an embodied communication ... embodiment can become a tool as well as a text. In this encounter, the researchers, venturing into new intellectual (and often emotional) terrains, are willing to let themselves be touched and changed. (Bresler, 2006, p. 32)

Tools work on the researcher as well as the researched: "The 'flesh' of mindful embodiment yields a texture belonging as much to the other as self" (Latta \& Buck, 2008, p. 322). If we are willing-and often even when we are not-we experience profound changes in our sense of who we are and how we live in the world as our sense making alters in response to every interview encounter.

\section{EMBODIED STRATEGIES FOR DATA ANALYSIS}

Data analysis may be enriched with consideration of embodiment woven throughout the process of discerning patterns or uncovering and constructing meanings (e.g., grounded theory, cultural studies critique). I will discuss issues of embodied representation in the next section; however, I should point out that decisions about analytic frameworks and techniques overlap with those about representation, since some genres, media, and audiences pair more readily with some modes of analysis than do others. So while my focus in each of these sections differs, the two may be considered even more closely intertwined than are all of the issues about research processes discussed in this chapter.

For most qualitative researchers, the beginnings of analysis coincide with data collection, as we make notes to ourselves about emergent topics and themes, our impressions of participants' affect during interviews, and connections to existing research (e.g., Lindlof \& Taylor, 2011), and as I argued earlier, transcription of interviews also involves analytic choices (Mishler, 1991). During the in-depth analysis of transcripts and notes, researchers may engage in what is generally known as reflexivity, a fairly standard component of qualitative methods across the continuum of such methods, except those near the scientific/positivist end (i.e., as far from the artistic/interpretive pole as possible) (Ellingson, 2009). Reflexivity includes many variations, and important epistemological, ontological, and methodological debates persist concerning what it means to be reflexive about researchers' involvement in meaning making (e.g., Alvesson \& Skoldberg, 2000; Downe, 2007; Ezzy, 2010; Finlay, 2002; Hall \& Callery, 2001; Macbeth, 2001; Madison, 2005; Pillow, 2003; Stronach, Garratt, Pearce, \& Piper, 2007), all of which address embodiment to a greater or lesser extent. For interview research, I hold three particular aspects of reflexivity critical to engaging embodiment as a meaningful component of data analysis.

First, continually return attention to the mutual embodiment of both researcher(s) and participants in the interview data under analysis. To "limi $[t]$ the exploration of embodiment to the other" places researchers in a "position of power that can be exploitive" of participants (Sharma et al., 2009, pp. 16471648; see also Edvardsson \& Street, 2007). Mutuality does not erase the differences of power between participants and researchers; instead, it serves as a way to ground verbal texts in the complex realities of the intersubjective process from which they arose-that is, a conversation between (material) bodies.

Second, harness the materiality of data analysis processes. That is, pay attention to the ways in which analysis involves physical creation and manipulation of textual objects and the ways of seeing and understanding promoted by these processes (Konopásek, 2008). Konopásek (2008) explains that "analytical work is in an important sense a material praxis (and vice versa)" (para. 30). Using computer programs that assist with qualitative data analysis, "we can create, 
see and manipulate various objects. These objects can be of different sizes and shapes; they can be hidden, moved, split, colourised, grouped and regrouped, forgotten and rediscovered on unexpected occasions" (para. 20). Likewise, those who have used and/or continue to use printed paper copies, colored pens and pencils, scissors, paper clips, and so on for data coding and manipulation create new objects (groupings of quotes and notes) within a "textual laboratory-which has the power to shrink time and space distances between observable phenomena so that everything important is present and under control" (para. 22). The grouping, networking, coding, and commenting on of quotes enables researchers to visualize connections among ideas, deeply affecting our continual construction of meaning.

Third, consider the degree to which emergent themes or other developing findings implicate specific bodily states, practices, definitions, and experiences. Cast a discerning eye over the preliminary collection of quotes (or other evidence), and consider how participants describe their own bodily appearance, bodily sensations (e.g., pleasure as well as discomfort or pain), and experiences of bodily breakdown or failure. Also note participants' descriptions of others' responses to their bodies (e.g., how a boyfriend described her hips, how a coach criticized his calf muscles) and their thoughts and feelings about those past responses. Consider how participants' discussions of abstract principles (e.g., respect, authority) are grounded in gestures, facial expressions, or other embodied signals. Charmaz (2006) admonishes researchers to "never leave their data" (i.e., to continually refer back to data) when constructing typologies of themes because of the risk of developing themes not sufficiently grounded in participants' talk and based too much in researcher's thoughts. In the same way, I admonish researchers conducting analysis to never leave the body when constructing themes-to continually reflect on how themes reflect bodies and the interaction of bodies even as they encapsulate more abstract patterns of meaning.

\section{EMBODIED REPRESENTATIONAL STRATEGIES}

One way to position the body as producing knowledge is to write autoethnographically about the research process (Ellis, 1997). Ellis and Bochner (2000) described autoethnography as revealing the connections of the

personal to the cultural.... [Autoethnographers focus] outward on social and cultural aspects of their personal experience; then, they look inward, exposing a vulnerable self that is moved by and may move through, refract, and resist cultural interpretations. (p. 739)

Autoethnography blurs the lines between the sciences and humanities (e.g., Ellingson, 1998; Ellis \& Bochner, 2000) and problematizes the differentiation between researcher and researched (DeVault, 1990; Mies, 1983; Reinharz, 1992). For example, narrative and autoethnographic methods acknowledge the dialogic construction of patients' constructions of the meaning of their illness with researchers' embodied experiences (Frank, 1995). Rather than simply being the narrator or reporter of findings, the researcher serves as the main character of a story that parallels the academic narrative contained in the research report (see also Sara Crawley's chapter, "Autoethnography as Feminist Self-Interview," this volume). In layered accounts, researchers alternate sections of an article written using social science conventions (i.e., citation of relevant research and theory, presentation of a research question, explanation of methods) with brief narratives that show rather than tell about aspects of the research (Ronai, 1995); alternatively, such narratives can be placed at the beginning or end of the conventional analysis (e.g., Ellis, 1993). Autoethnographic narratives (potentially) offer embodied details, celebrate the author's position, problematize the production of knowledge, and reveal the profane in the sacred processes of interview research.

Of course, many venues do not welcome autoethnographic accounts, and not all researchers are comfortable with such forms of representation, even as supplements to other, more social-scientific analyses of the same data. It is vital to maintain a wide range of accepted genres for disseminating qualitative research. Thus, I also explore ways in which researchers' bodies can be represented in conventionally written interview research reports.

First, as other qualitative methodologists have suggested, researchers could pay more careful attention to all of their senses as they conduct interviews and include relevant details in the "thick description" of 
their findings (Geertz, 1973). In interview research, we want to describe our participants' meanings using concrete details about their experiences, thoughts, and feelings. Yet those descriptions of individuals in specific moments must resonate with the larger themes of the research; that is, each particular example must illustrate a broader category while retaining its ability to embody some specific aspect of an individual's life. Thus, interviewers should record as much detail as possible during interviews and then select with great care which details to include in their reports and other representations.

Second, be conscious of the direct and indirect ways in which we show up in our work. Use the first person to own your actions: $I$ collected the data, $I$ conducted analyses, $I$ sought institutional review board approval, and so on. First-person voice usually provides the most concise way of describing research processes, findings, and implications. In addition to being present as an authorial "I," let readers know who you are in your project. Describing your standpoints can be done in the introduction or methods section or in a footnote if the outlet does not approve or if such an explanation might distract from an essay or story's aesthetic goals.

Another way to bring the body into analytic writing is to wrestle with the semantics of the body, including framing the body as the self rather than adhering to the Cartesian model, in which the body is the lowly property of the (higher) mind-self (i.e., I moved my body). The difficulty lies in writing intelligibly while also reflecting the embodied nature of knowledge in our body-selves. Trinh (1991), for example, discussed the "subjectivity of a non-I/plural I" (p. 192) as a strategy to counter hegemonic Western conceptualizations of the self. Along similar lines, Irigaray (1980) invoked you/I, I/you, and you/me in her discussion of the need for plurality of identity rather than reaffirmation of dichotomies (e.g., male/ female, culture/nature). When I construct a research report or other representation, I struggle with language, almost inevitably linguistically possessing "my" body instead of equating or connecting body and self. The only example of blurring the mind and body I have been successful in gaining editorial approval for is in the autoethnographic reflection chapter of my ethnography of a geriatric oncology (i.e., cancer) team: "The sharp sound of pagers rips open a scab I hadn't known still lingered on my psyche, and I gasp as the blood/memory flows" (Ellingson, 2005, p. 95). This move was easier to accomplish because it was in the context of narrative writing; such a strategy would be far more disruptive to the reader if it were placed in a more structured qualitative analysis. I encourage researchers to (gently) push the boundaries of writing conventions by trying out unusual phrasing of the body/self when doing so would enhance meaning and illuminate an embodied account of your interview research (see the discussion of "guerilla scholarship" in Ellingson, 2009, pp. 134-136).

\section{$\checkmark$ Conclusion}

I opened this chapter with a quotation from Nancy Mairs, a poet and essayist who lives with multiple sclerosis. Her remarkable essay about writing, voice, and embodiment, "Carnal Acts," echoes many of the themes of embodiment that I have discussed in the context of interviewing practices. Mairs (1997) boldly asserts the need to speak our bodily truths, particularly those that have been silenced and shamed through systems of sexism, racism, classism, homophobia, ableism, and other powerful discourses that continue to inscribe indelible bodily difference on some while privileging others by positioning their bodies as irrelevant to knowledge construction. In a world of complex intersections of identities and experience, interviewing is a potentially powerful method for examining meanings in ways that acknowledge our embodied being in the world. This chapter has offered a number of practical suggestions for focusing on embodiment while preparing for, collecting, analyzing, and representing interviews. Reflecting on the role of interviewers' and interviewees' bodies at every stage of the interview process circumvents the temptation to simplify findings either by ignoring the realities of bodily differences or conversely by essentializing bodies as inherently constituting certain meanings. Conscious embodiment undoes traditional mind/body dichotomies by joining the material with the socially constructed and enabling us to co-construct research findings that are both richly nuanced and grounded in the material realities of our contemporary global world.

\section{$\checkmark$ References}

Adler, R. B., \& Towne, N. (2005). Looking out, looking in: Interpersonal communication (11th ed.). Fort Worth, TX: Harcourt Brace. 
Alvesson, M., \& Skoldberg, K. (2000). Reflexive methodology. Thousand Oaks, CA: Sage.

Barnacle, R. (2009). Gut instinct: The body and learning. Educational Philosophy and Theory, 41, 22-33.

Blumer, H. (1954). Symbolic interactionism: Perspective and method. Englewood Cliffs, NJ: Prentice Hall.

Bresler, L. (2006). Embodied narrative inquiry: A methodology of connection. Research Studies in Music Education, 27, 21-43.

Brown, L., \& Boardman, F. K. (2010). Accessing the field: Disability and the research process. Social Science and Medicine, 72(1), 23-30. doi:10.1016/j.socscimed .2010 .09 .050

Burns, M. (2003). Interviewing: Embodied communication. Feminism \& Psychology, 13, 229-236.

Charmaz, K. (2006). Constructing grounded theory: A practical guide through qualitative analysis. Thousand Oaks, CA: Sage.

Coles, R. C. (2001). The parenting roles and goals of single black full-time fathers. Western Journal of Black Studies, 25, 101-116.

Colley, A., \& Todd, Z. (2002). Gender-linked differences in the style and content of e-mails to friends. Journal of Language and Social Psychology, 21, 380-392.

Colombetti, G., \& Thompson, E. (2008). The feeling body: Toward an enactive approach to emotion. In W. F. Overton, U. Müller, \& J. L. Newman (Eds.), Developmental perspectives on embodiment and consciousness (pp. 45-68). New York, NY: Lawrence Erlbaum.

Davis, A. (1990). Women, culture, and politics. New York, NY: Vintage Books.

Del Busso, L. (2007). Embodying feminist politics in the research interview: Material bodies and reflexivity. Feminism \& Psychology, 17, 309-315.

Denzin, N. K. (1997). Interpretive ethnography: Ethnographic practices for the 21st century. Thousand Oaks, CA: Sage.

Denzin, N. K., \& Lincoln, Y. S. (2000). Introduction: The discipline and practice of qualitative research. In N. K. Denzin \& Y. S. Lincoln (Eds.), Handbook of qualitative research (2nd ed., pp. 1-28). Thousand Oaks, CA: Sage.

DeVault, M. L. (1990). Talking and listening from women's standpoint: Feminist strategies for interviewing and analysis. Social Problems, 37, 96-116.

Downe, P. J. (2007). Strategic stories and reflexive interruptions: Narratives of a "safe home" amidst crossborder sex work. Qualitative Inquiry, 13, 554-572.

Dumas, A., Laberge, S., \& Straka, S. M. (2005). Older women's relations to bodily appearance: The embodiment of social and biological conditions of existence. Ageing \& Society, 25, 883-902.

du Pre, A. (2009). Communicating about health: Current issues and perspectives (3rd ed.). New York, NY: Oxford University Press.
Edvardsson, D., \& Street, A. (2007). Sense or no-sense: The nurse as embodied ethnographer. International Journal of Nursing Practice, 13, 24-32.

Ellingson, L. L. (1998). "Then you know how I feel”: Empathy, identification, and reflexivity in fieldwork. Qualitative Inquiry, 4, 492-514.

Ellingson, L. L. (2003). Interdisciplinary health care teamwork in the clinic backstage. Journal of Applied Communication Research, 31, 93-117.

Ellingson, L. L. (2005). Communicating in the clinic: Negotiating frontstage and backstage teamwork. Cresskill, NJ: Hampton Press.

Ellingson, L. L. (2006). Embodied knowledge: Writing researchers' bodies into qualitative health research. Qualitative Health Research, 16, 298-310.

Ellingson, L. L. (2009). Engaging crystallization in qualitative research: An introduction. Thousand Oaks, CA: Sage.

Ellingson, L. L. (2011). The poetics of professionalism among dialysis technicians. Health Communication, 26(1), 1-12.

Ellis, C. (1993). "There are survivors": Telling a story of sudden death. The Sociological Quarterly, 34, 711-730.

Ellis, C. (2004). The ethnographic I: A methodological novel about autoethnography. Walnut Creek, CA: AltaMira Press.

Ellis, C., \& Bochner, A. P. (2000). Autoethnography, personal narrative, reflexivity: Researcher as subject. In N. K. Denzin \& Y. S. Lincoln (Eds.), Handbook of qualitative research (2nd ed., pp. 733-768). Thousand Oaks, CA: Sage.

Evans, H. M. (2010). The art of medicine: Music, medicine, and embodiment. The Lancet, 375, 886-887.

Ezzy, D. (2010). Qualitative interviewing as an embodied emotional performance. Qualitative Inquiry, 16, 163-170.

Fine, M., Weis, L., Weseen, S., \& Wong, L. (2000). For whom? Qualitative research, representation, and social responsibilities. In N. K. Denzin \& Y. S. Lincoln (Eds.), Handbook of qualitative research (2nd ed., pp. 107-132). Thousand Oaks, CA: Sage.

Finlay, L. (2002). "Outing" the researcher: The provenance, process, and practice of reflexivity. Qualitative Health Research, 12, 531-545.

Frank, A. W. (1995). The wounded storyteller: Body, illness, and ethics. Chicago, IL: University of Chicago Press.

Geertz, C. (1973). The interpretation of cultures. New York, NY: Basic Books.

Gergen, K. J. (1994). Realities and relationships: Soundings in social construction. Cambridge, MA: Harvard University Press.

Goffman, E. (1959). The presentation of self in everyday life. Garden City, NY: Doubleday.

Goldberg, N. (1986). Writing down the bones: Freeing the writer within. Boston, MA: Shambhala. 
Haddow, G. (2005). The phenomenology of death, embodiment and organ transplantation. Sociology of Health \& Illness, 92-113.

Hall, W. A., \& Callery, P. (2001). Enhancing the rigor of grounded theory: Incorporating reflexivity and relationality. Qualitative Health Research, 11, 257-272.

Haraway, D. (1988). Situated knowledges: The science question in feminism and the privilege of partial perspective. Feminist Studies, 14, 575-599.

Hayward, C. (Director), \& Harter, L. M. (Producer). (2010). The art of the possible [Motion picture]. Athens: University of Ohio.

Hegland, M. E. (2009). Losing, using, and crafting spaces for aging: Muslim Iranian American seniors in California's Santa Clara Valley. In J. Sokolovsky (Ed.), The cultural context of aging: World wide perspectives (pp. 302-324). Westport, CT: Greenwood.

Hochschild, A. R. (1983). The managed heart: Commercialization of human feeling. Berkeley: University of California Press.

Holstein, J. A., \& Gubrium, J. F. (1995). The active interview. Thousand Oaks, CA: Sage.

Holstein, J. A., \& Gubrium, J. F. (2003). Active interviewing. In J. F. Gubrium \& J. A. Holstein (Eds.), Postmodern interviewing (pp. 67-80). Thousand Oaks, CA: Sage.

Inckle, K. (2007). Writing on the body? Thinking through gendered embodiment and marked flesh. Newcastle, England: Cambridge Scholars.

Irigaray, L. (1980). When our lips speak together (C. Burke, Trans.). Signs: Journal of Women in Culture and Society, 6, 69-79.

Jacobson, D. (1999). Impression formation in cyberspace: Online expectations and offline experiences in textbased virtual communities. Journal of ComputerMediated Communication, 5. Retrieved from http:// jcmc.indiana.edu/vol5/issue1/jacobson.html

Janesick, V. J. (2011). Stretching exercises for qualitative researchers ( $3 \mathrm{rd}$ ed.). Thousand Oaks, CA: Sage.

Johnson, M. (1987). The body in the mind: The bodily basis of meaning, imagination, and reasoning. Chicago, IL: University of Chicago Press.

Konopásek, Z. (2008). Making thinking visible with Atlas.ti: Computer assisted qualitative analysis as textual practices. Forum Qualitative Sozialforschung/ Forum: Qualitative Social Research, 9(2), Art. 12. Retrieved from http://www.qualitative-research.net/ index.php/fqs/article/view/420/911

Latta, M. M., \& Buck, G. (2008). Enfleshing embodiment: "Falling into trust" with the body's role in teaching and learning. Educational Philosophy and Theory, 40, 315-329.

Lindlof, T. R., \& Taylor, B. C. (2011). Qualitative communication research methods (3rd ed.). Thousand Oaks, CA: Sage.
Lovink, G. (2005). Talking race and cyberspace: An interview with Lisa Nakamura. Frontiers, 26, 60-65.

Macbeth, D. (2001). On "reflexivity" in qualitative research: Two readings and a third. Qualitative Inquiry, 7, 35-68.

Madison, D. S. (2005). Critical ethnography: Method, ethics, and performance. Thousand Oaks, CA: Sage.

Mairs, N. (1997). Carnal acts. In K. Conboy, N. Medina, \& S. Stanbury (Eds.), Writing on the body: Female embodiment and feminist theory (pp. 296-305). New York, NY: Columbia University Press.

Mann, C., \& Stewart, F. (2002). Internet interviewing. In J. F. Gubrium \& J. A. Holstein (Eds.), Handbook of interview research: Context and method (pp. 603-628). Thousand Oaks, CA: Sage.

Marshall, H. (1999). Our bodies, ourselves: Why we should add old fashioned empirical phenomenology to the new theories of the body. In J. Price \& M. Shildrick (Eds.), Feminist theory and the body: A reader (pp. 64-75). New York, NY: Routledge.

Mies, M. (1983). Towards a methodology for feminist research. In G. Bowles \& R. D. Klein (Eds.), Theories of women's studies (pp. 117-138). London, England: Routledge.

Miller-Day, M. A. (2004). Communication among grandmothers, mothers, and adult daughters: A qualitative study of maternal relationships. Mahwah, NJ: Lawrence Erlbaum.

Minge, J. M. (2007). The stained body: A fusion of embodied art on rape and love. Journal of Contemporary Ethnography, 36, 252-280.

Minow, M. (1990). Making all the difference: Inclusion, exclusion and the American law. Ithaca, NY: Cornell University Press.

Mishler, E. G. (1991). Representing discourse: The rhetoric of transcription. Journal of Narrative and Life History, 1, 255-280.

Murray, C. D. (2004). An interpretative phenomenological analysis of the embodiment of artificial limbs. Disability and Rehabilitation, 26, 963-973.

Peralta, R. L. (2007). College alcohol use and the embodiment of hegemonic masculinity among European American men. Sex Roles, 56, 741-756.

Pillow, W. (2003). Confession, catharsis, or cure? Rethinking the uses of reflexivity as methodological power in qualitative research. International Journal of Qualitative Studies in Education, 16, 175-196.

Pollock, D. (1999). Telling bodies, performing birth. New York, NY: Columbia University Press.

Price, J., \& Shildrick, M. (Eds.). (1999). Feminist theory and the body: A reader. New York, NY: Routledge.

Quinlan, M. M. (2010). Fostering connections among diverse individuals through multi-sensorial storytelling. Health Communication, 25, 91-93. 
Quinlan, M. M., \& Harter, L. M. (2010). Meaning in motion: The embodied poetics and politics of Dancing Wheels. Text and Performance Quarterly, 30, 374-395.

Reinharz, S. (1992). Feminist methods in social research. New York, NY: Oxford University Press.

Roen, K. (2001). Transgender theory and embodiment: The risk of racial marginalisation. Journal of Gender Studies, 10, 253-263.

Román-Velázquez, P. (1999). The embodiment of salsa: Musicians, instruments and the performance of a Latin style and identity. Popular Music, 18, 115-131.

Ronai, C. R. (1992). Managing aging in young adulthood: The "aging" table dancer. Journal of Aging Studies, 6, 307-317.

Ronai, C. R. (1995). Multiple reflections of childhood sex abuse: An argument for a layered account. Journal of Contemporary Ethnography, 23, 395-426.

Rose, G. (1999). Women and everyday spaces. In J. Price \& M. Shildrick (Eds.), Feminist theory and the body: A reader (pp. 359-370). New York, NY: Routledge.

Schrock, D., Reid, L., \& Boyd, E. M. (2005). Transsexuals' embodiment of womanhood. Gender \& Society, 19, 317-335.

Sharma, S., Reimer-Kirkham, S., \& Cochrane, M. (2009). Practicing the awareness of embodiment in qualitative health research: Methodological reflections. Qualitative Health Research, 19, 1642-1650.

Shuy, R. W. (2002). In-person versus telephone interviewing. In J. F. Gubrium \& J. A. Holstein (Eds.), Handbook of interview research: Context and method (pp. 537-556). Thousand Oaks, CA: Sage.
Simmonds, F. N. (1999). My body, myself: How does a black woman do sociology? In J. Price \& M. Shildrick (Eds.), Feminist theory and the body: A reader (pp. 50-63). New York, NY: Routledge.

Spivak, G. (1987). In other worlds: Essays in cultural politics. New York, NY: Routledge.

Stelter, R. (2010). Experience-based, body-anchored qualitative research interviewing. Qualitative Health Research, 20, 859-867.

Stronach, I., Garratt, D., Pearce, C., \& Piper, H. (2007). Reflexivity, the picturing of selves, the forging of method. Qualitative Inquiry, 13, 179-203.

Tanis, M., \& Postmes, T. (2003). Social cues and impression formation in CMC. Journal of Communication, 53, 676-693.

Todres, L. (2008). Being with that: The relevance of embodied understanding for practice. Qualitative Health Research, 18, 1566-1573.

Trinh, T. M. (1991). When the moon waxes red: Representation, gender and cultural politics. New York, NY: Routledge.

Trinh, T. M. (1999). Write your body: The body in theory. In J. Price \& M. Shildrick (Eds.), Feminist theory and the body: A reader (pp. 258-266). New York, NY: Routledge.

Walsh, D. J. (2010). Childbirth embodiment: Problematic aspects of current understandings. Sociology of Health or Illness, 32, 486-501.

Wittgenstein, L. (1953). Philosophical investigations. Malden, MA: Blackwell.

Zitzelsberger, H. (2005). (In)visibility: Accounts of embodiment of women with physical disabilities and differences. Disability \& Society, 20, 389-403. 


\section{ABOUT THE EDITORS}

Jaber F. Gubrium is Professor and Chair of Sociology at the University of Missouri. He has an extensive record of research on identity in everyday life and the social organization of care in human service institutions. His publications include numerous books and articles on aging, family, the life course, medicalization, and representational practice in a therapeutic context.

James A. Holstein is Professor of Sociology in the Department of Social and Cultural Sciences at Marquette University. His research and writing have addressed social problems, deviance and social control, mental health and illness, family, and the self, all approached from an ethnomethodologically informed, constructionist perspective.

Collaborating for more than 25 years, Gubrium and Holstein have authored and edited dozens of books, many of them dealing with qualitative research methods and interviewing, including Varieties of Narrative Analysis, Analyzing Narrative Reality, The New Language of Qualitative Method, The Active Interview, Handbook of Constructionist Research, Handbook of Interview Research (first edition), The Self We Live By, Constructing the Life Course, and What Is Family?
Amir B. Marvasti is Associate Professor of Sociology at Pennsylvania State University, Altoona. His research focuses on the social construction of deviant identities. $\mathrm{He}$ is the author of Being Homeless: Textual and Narrative Constructions (Lexington Books, 2003), Qualitative Research in Sociology (Sage, 2003), Middle Eastern Lives in America (with Karyn McKinney; Rowman \& Littlefield, 2004), and Doing Qualitative Research: A Comprehensive Guide (with David Silverman; Sage, 2008). His articles have been published in Journal of Contemporary Ethnogra phy, Qualitative Inquiry, Symbolic Interaction, and Critical Sociology.

Karyn D. McKinney is Associate Professor of Sociology and Women's Studies at Pennsylvania State University, Altoona. Her research has focused on the role of race and racism in identity construction. Her publications include Being White: Stories of Race and Racism (Routledge, 2005), Middle Eastern Lives in America (with Amir Marvasti; Rowman \& Littlefield, 2004), and The Many Costs of Racism (with Joe Feagin; Rowman \& Littlefield, 2003). In addition, she has published articles in journals such as Race and Society, Social Identities, and Critical Sociology. 


\section{ABOUT THE CONTRIBUTORS}

Robert Atkinson is Professor of Human Development, Multicultural Studies, and Religious Studies, director of: the Life Story Center, and senior research fellow at the Osher Lifelong Learning Institute (OLLI) National Resource Center at the University of Southern Maine (USM), where he has been since 1987. He is the author, coauthor, or editor of seven books, including Latino Voices in New England (SUNY Press, 2009); his memoir, Remembering 1969: Searching for the Eternal in Changing Times (2008); The Beat of My Drum: An Autobiography (assisting Babatunde Olatunji, 2005); The Life Story Interview (Sage, 1998; translated into Italian, 2002, and Romanian, 2006); and The Gift of Stories: Practical and Spiritual Applications of Autobiography, Life Stories, and Personal Mythmaking (1995; translated into Japanese, 2005). He was a faculty member on the Semester at Sea program of the University of Virginia, sailing around the world in 100 days and visiting 10 countries, in the fall of 2002. From 2002 to 2004, he served as the first Diversity Scholar for the College of Education and Human Development at USM. His website for the Life Story Center, on the home page of the OLLI National Resourse Center, features a searchable archive of 300 life stories and an interactive life storytelling protocol.

Ben K. Beitin is an associate professor of marriage and family therapy at Seton Hall University. His research has focused on couple relationships and coping and expanded into an interest in the wonders and complexities of interviewing partners and family members together in qualitative research. He has published several chapters and articles related to interviewing couples and families, social justice, diversity, and the interactions between family systems and societies. He has been recently studying health and relationships in immigrant couples.

Linda Liska Belgrave is an associate professor of sociology at the University of Miami. Her scholarly interests are primarily in the substantive areas. of medical sociology, social psychology, and social justice (broadly defined). She uses a variety of qualitative methods, including in-depth interviews, focus group interviews, participant observation, and variations on autoethnography, to pursue topics such as elders' experiences and definitions of well-being, the daily lives of African American caregivers of family members with Alzheimer's disease, and, most recently, political controversy in the classroom from the perspectives of both faculty and students. She currently serves as chair for a National Institutes of Health Special Emphasis Panel/Scientific Review Group on Health Literacy.

Christian L. Bolden is an assistant professor in criminology at Indiana University, Pennsylvania. His current research interests include reconciling interpretations of gang behaviors and processes with the viewpoints of actual gang members, 
examining the social network dynamics of populations labeled as deviant, assessing territory and crime hot spots through GIS crime mapping, and studying homicide trends. His recent work can be found in the Journal of Gang Research and Deviant Behavior.

Michael Ian Borer is an associate professor of sociology at the University of Nevada, Las Vegas. He is the author of Faithful to Fenway: Believing in Boston, Baseball, and America's Most Beloved Ballpark (NYU Press, 2008) and editor of Varieties of Urban Experience: The American City and the Practice of Culture (2006). He has published articles in City and Community, Journal of Popular Culture, and Symbolic Interaction, among others. He is currently coauthoring a textbook on the connections between the cultures and communities in cities, suburbs, and towns and is conducting ethnographic research on people watching and the sacred landscape of Las Vegas. He is the 2011-2012 vice president of the Society for the Study of Symbolic Interaction.

Hugh Busher is a senior lecturer in education, University of Leicester, UK. Using mainly qualitative and visual methods, he is currently researching students' and teachers' perspectives on education and teaches courses on research methods, on leadership of inclusive schooling and learning communities. Among his more recent publications are Understanding Educational Leadership: People, Power and Culture and, with Nalita James, Online Interviewing.

Shannon K. Carter is an assistant professor of sociology at the University of Central Florida. Her primary research interest is gender and reproduction, with an emphasis on narratives of the body. Her work is published in journals such as Sociology of Health \& Illness, Gender Issues, National Women's Studies Association Journal, and Journal of Family Issues. Her current research focuses on public discourses of breast-feeding and race differences in women's institutional breast-feeding experiences.

Kathy Charmaz is a professor of sociology and the director of the Faculty Writing Program at Sonoma State University, California, a program that supports faculty members' scholarly writing. Her research interests include the experience of illness and disability, the social psychology of time, and ethics in qualitative research. She has written, coauthored, or coedited nine books, including Constructing Grounded
Theory: A Practical Guide Through Qualitative Analysis, which received a Critics' Choice award from the American Educational Studies Association and has been translated into Chinese, Japanese, Polish, and Portuguese. Her recent multiauthored books are Five Ways of Doing Qualitative Analysis: Phenomenological Psychology, Grounded Theory, Discourse Analysis, Narrative Research, and Intuitive Inquiry and Developing Grounded Theory: The Second Generation. She recently received the Goldstein award for scholarship from Sonoma State University and has also received the George Herbert Mead award for Lifetime Achievement and the Feminist Mentors Award from the Society for the Study of Symbolic Interaction. Throughout her career, she has conducted professional development workshops and classes on grounded theory methods, intensive interviewing, and writing for publication.

Kay E. Cook is a senior research fellow in the Centre for Applied Social Research at RMIT University, Melbourne, Auștralia. She is a sociologist who uses qualitative methods, particularly critical approaches, to explore how social policies affect the lives of marginalized groups. This work has an explicitly political focus and has contributed to several government inquiries and reforms, including the recent Australian Law Reform Commission inquiry into family violence and family law. Her recent nationally funded grants have examined the health and social consequences of Australia's welfare-to-work reforms and the impact of erratic child support payments on the social inclusion of low-income children.

Sara L. Crawley is an associate professor of sociology at the University of South Florida and regularly teaches in the Department of Women's and Gender Studies. Trained in both qualitative sociology and women's studies, Crawley focuses on the interdisciplinary space compelled by feminist and queer theories, especially on and about topics of the body and bodily experience, and regularly employs autoethnography as method. Crawley's book Gendering Bodies (coauthored with Lara J. Foley and Constance L. Shehan) adds interpretive sociology to gender and sexualities theories to explain how gender gets written on and produced by bodies. Having published autoethnographic work in Feminism and Psychology, Feminist Teacher, Journal of Lesbian Studies, Journal 
of Contemporary Ethnography, and Cultural Studies $\leftrightarrow$ Critical Methodologies, Crawley recently was invited to hold workshops on feminist theory, queer theory, and interpretive methods in Ukraine for scholars from post-Soviet countries; some of Crawley's works have recently been translated into Russian.

Marjorie L. DeVault is professor of sociology in the Maxwell School of Citizenship and Public Affairs at Syracuse University. Her research focuses on gender and work, including unpaid household and family work, and she has written extensively on qualitative and feminist research methodologies, especially institutional ethnography. She is the author of Feeding the Family: The Social Organization of Caring as Gendered Work and Liberating Method: Feminism and Social Research and editor of People at Work: Life, Power, and Social Inclusion in the New Economy.

Ingunn T. Ellingsen is a qualified social worker and a research associate professor in the Faculty of Social Sciences at the University of Stavanger, Norway. Her doctoral thesis was based on her research on family perceptions in child welfare settings. In this research, she used Q methodology as the main data collection instrument.

Laura L. Ellingson is an associate professor of Communication Studies and Women's \& Gender Studies at Santa Clara University. She teaches courses in qualitative methods, feminist methods, health communication, communication and gender, and gender, health, and sexuality. Her research focuses on gender in extended families, feminist and qualitative methodologies, embodiment, and interdisciplinary teamwork in health care organizations. She is the author of Communicating in the Clinic: Negotiating Frontstage and Backstage Teamwork (2005, Hampton) and Engaging Crystallization in Qualitative Research (2009, Sage) and coauthor with Patty Sotirin of Aunting: Cultural Practices That Sustain Family and Community Life (2010, Baylor University Press). She is the senior editor for Qualitative, Interpretive, and Rhetorical Methods and senior editor of the Defining Moments section of the journal Health Communication. She has served as president of the Organization for the Study of Communication, Language, and Gender and as chair of the Ethnography Division of the National Communication Association. Currently, she is investigating representations of aunts in contemporary North American popular culture and the personal, professional, and health care experiences of long-term cancer survivors living with the "late effects" of treatment.

Christopher A. Faircloth is an associate professor and chair of the Department of Sociology at Xavier University, Louisiana. His primary research interests are the "chronic illness experience," health disparities, sociology of the body, interpretive sociology, and qualitative research methods. He has edited or coedited two volumes, Aging Bodies (AltaMira Press) and Medicalized Masculinities (Temple University Press), with Dana Rosenfeld. In addition, he has published numerous articles in journals such as Sociology of Health and Illness, Qualitative Health Research, Ageing and Society, and Journal of Aging Studies. He is currently researching the effects that the treatment of leukemia and lymphoma have on perceptions of body and self among cancer patients. He served as the 2010-2011 vice president for the Society for the Study of Symbolic Interactionism and is on the editorial board of Symbolic Interaction.

Linda Finlay is an integrative-existential psychotherapist and freelance academic consultant. In addition to her psychotherapy practice, she teaches psychology and writes for the Open University, United Kingdom. She also offers training and mentorship on how to do qualitative research. Her particular interests include working with trauma and researching the lived experience of disability using phenomenological approaches that embrace hermeneutic, reflexive, and relational forms. She has published widely, including Reflexivity: A Practical Guide for Researchers in Health and Social Science, a volume coedited with Brendan Gough; Qualitative Research for Allied Health Professionals, a volume coedited with Claire Ballinger; Relational Centred Research for Psychotherapists, a book coauthored with Ken Evans; and, most recently, Phenomenology for Therapists (2011, Wiley).

Lara J. Foley is Chair and Associate Professor of Sociology at the University of Tulsa. She is also codirector of the University of Tulsa Institute for Trauma, Abuse and Neglect. Her research focuses on gender and occupational identity, especially in medical and legal fields. She is the coauthor of Gendering Bodies (2008, with Sara L. Crawley and Constance L. Shehan) as well as numerous articles.

Andrea Fontana is Professor Emeritus of Sociology at the University of Nevada, Las Vegas. He has published 
articles on aging, leisure, theory; and postmodernism. $\mathrm{He}$ is the author of the Last Frontier: The Social Meaning of Growing Old, coauthor of Social Problems, Sociologies of Everyday Life, and coeditor of The Existential Self in Society and Postmodernism and Social Inquiry. He is a former president of the Society for the Study of Symbolic Interaction and a former editor of the journal Symbolic Interaction. Among his last published essays are a deconstruction of the work of the painter Hieronymus Bosch; a performance/play about Farinelli, the castrato; an ethnographic narrative about land speed records at the Bonneville Salt Flats; and a performance based on Six Feet Under. He recently published The Interview: From Formal to Postmodern and Death in America.

Kenneth M. George has been Professor of Anthropology at the University of Wisconsin-Madison since 1999, having served previously at Harvard University and the University of Oregon. $\mathrm{He}$ is a specialist on Southeast Asia and a past editor of the Journal of Asian Studies (2005-2008). His ethnographic research in Indonesia has focused on the cultural politics of minority ancestral religions (1982-1992) and, more recently (1994-2008), on a long-term collaboration with the painter A. D. Pirous, exploring the aesthetic, ethical, and political ambitions shaping Islamic art and art publics in that country. His books include Showing Signs of Violence: The Cultural Politics of a TwentiethCentury Headhunting Ritual, awarded the 1998 Harry J. Benda Prize for best book on Southeast Asia by the Association for Asian Studies; Picturing Islam: Art and Ethics in a Muslim Lifeworld; and Spirited Politics: Religion and Public Life in Contemporary Southeast Asia (coedited with Andrew C. Willford). Ken has been the recipient of major postdoctoral fieldwork fellowships from the Social Science Research Council, the Wenner-Gren Foundation for Anthropological Research, and the Aga Khan Trust for Culture. His fellowships for writing and study include awards from the National Endowment of the Humanities, the John Simon Guggenheim Foundation, and the Institute for Advanced Study. His early work on personal narrative in evangelical oratory appeared in the pages of Alcheringa: Ethnopoetics.

Anne Grinyer is a medical sociologist and senior lecturer in the Division of Health Research at Lancaster University. Her research over the past 10 years has focused on the life stage effects of cancer in teenagers and young adults and covers four main phases.
The first phase focused on the impact a cancer diagnosis at this age has on family dynamics, particularly in terms of the life stage of the teenagers and young adults. The second phase was based on interviews with young adults with cancer to understand the life stage issues from their perspective. The third phase examined long-term survivorship and the ongoing impact of life stage at diagnosis. The fourth phase addressed palliative and end-of-life care for the age group and the challenge of providing age-appropriate care. Each phase of the research has resulted in a number of publications, including books based on the qualitative data collected from participants. The books are Cancer in Young Adults: Through Parents, Eyes (Open University Press, 2002), Young People Living With Cancer: Implications for Policy and Practice (Open University Press, 2007), Life After Cancer in Adolescence and Young Adulthood: Late Effects and Long Term Survivorship (Routledge, 2009), and Palliative and End of Life Care for Children and Young People: Hospital, Hospice and Home (Wiley, in press). She also has an interest in the ethics of health research and in research design and has published a number of articles on this topic.

Marilys Guillemin is an associate professor and the director of the Centre for Health and Society, School of Population Health, University of Melbourne, Australia. She teaches postgraduate subjects in qualitative research design and research methods, and health ethics. She has published widely in the areas of sociology of health, illness and technology, innovative research methodologies, research practice, narrative ethics, and ethical practice in research and in health care. She has completed a number of key research projects that include the management of menopause within specialized clinic settings; middleaged women and heart disease, particularly focusing on women's understanding of risk and prevention of heart disease; deafness and genetic testing; and examination of how ethics committee members and health researchers understand research ethics and how they address ethical issues in practice. She is the author (with Lynn Gillam) of Telling Moments: Everyday Ethics in Health Care (2006). Her current research focuses on the role of trust in human research from the perspectives of researchers and research participants.

Kristin Heggen is Professor of Health Sciences and Deputy Dean of Studies at The Faculty of Medicine, 
University of Oslo, Norway. Her scholarly work concentrates on professional education, focusing on the interdependence of liberal education and professional training. She has been involved in numerous studies of the power dynamics in health care, including care for the elderly, supervision of care, acute psychiatry, and acute hospital care. She is recognized for her expertise in qualitative methodologies, and she is an experienced user of unstructured observation in complex care settings and of interviews with participants who are patients, care persons, and health professionals. Her publications reflect an ongoing interest in research ethics practice. She teaches courses for master's degree and $\mathrm{PhD}$ students on general research design, qualitative methodology, and research ethics. A strong collaboration with Dr. Marilys Guillemin from The University of Melbourne, Australia, has led to an innovative narrative approach in the ethics education of novice researchers.

Alexa Hepburn is Reader in Conversation Analysis in the Social Sciences Department at Loughborough University. Her broad interests include theoretical and analytical innovations in psychology and understanding the rights and competencies of young people. Recent studies focus on the notation and analysis of laughing and crying, advice resistance, tag questions, aspects of self-repair, and threats in adult-child interaction, and the empirical grounding of these issues in a variety of data, for example, child protection help line phone calls and videos of family mealtimes. She is the author of An Introduction to Critical Social Psychology and coeditor (with Sally Wiggins) of Discursive Research in Practice. She is currently coauthoring Transcribing for Social Research (with Galina Bolden).

Hanna Herzog is a professor of sociology at Tel Aviv University and heads the interdisciplinary program on Women and Gender Studies. She is codirector, with Professor Naomi Chazan, of the Center for Advancement of Women in the Public Sphere at the Van Leer Jerusalem Institute in Israel. Herzog specializes in political sociology, political communication, sociology of knowledge, generation as a sociological phenomenon, and sociology of gender. She has written many articles and several books on the politics of ethnic and racial relations, women in politics and politics of women, Palestinian women citizens of Israel, Jewish women in the Holocaust, and gender, religion, and politics. Her works, based on qualitative research methods, analyze the reciprocal relations between the excluded and the excluders and the role of weakened groups in social structuring. As a feminist researcher, she emphasizes everyday activities and experiences as a part of social construction and social change.

Nalita James is lecturer in employment studies in the Centre for Labour Market Studies at the University of Leicester, England. She has used both online and offline qualitative research methods to research teachers' identities and learning, and is currently researching students' education to work transitions. She also teaches courses on, and writes about, qualitative research methods. Her recent research work has explored the use of the Internet in qualitative research. With Hugh Busher, she has presented and published widely on topics related to Internet interviewing. She is coauthor of Online Interviewing (2009) and continues to research and write about the methodological capacities of the Internet.

John M. Johnson is Professor of Justice Studies at Arizona State University, where he has taught for 40 years. $\mathrm{He}$ has used qualitative methods to study religious crusades, prisons, child abuse, sexual abuse, organizations, politics, violence against women, justice, human rights, and the death penalty. $\mathrm{He}$ is a former winner of the George Herbert Mead Award for outstanding career contributions to symbolic interaction and the Mentor Excellence Award, both from the Society for the Study of Symbolic Interaction. He has won many racquetball tournaments in his age division.

Karen Kaiser is a research assistant professor in the Department of Medical Social Sciences in the Feinberg School of Medicine at Northwestern University, Chicago. She utilizes qualitative and mixed methods to examine individual, interpersonal, organizational, social, and policy influences on health behaviors and health outcomes. Most recently, she has examined the experiences of women with breast cancer, racial and ethnic disparities in breast cancer, and patient experiences of cancer-related symptoms and side effects.

Annika Lillrank is senior lecturer of social work at the Swedish School of Social Science, University of Helsinki, Finland, and an associate professor of social work and health care at Jyväskylä University, Finland. Her scholarly work focuses on narrative methods in the study of health experience, and she has an extensive research record involving the study of parents' 
experiences of encounters with the health services in association with severe illness in their children and of pain sufferers in interaction with health care. Currently, she is working on a qualitative research project focusing on professional practices in maternity health care, seen from the point of view of pregnant immigrant women and their families.

Marco Marzano is a professor of sociology at the University of Bergamo, Italy. He has been a visiting scholar at many American and European universities. He cofounded and coedits Etnografia e Ricerca Qualitativa, the first Italian journal entirely devoted to qualitative research. His major interests include qualitative methodology, research ethics, death and dying, illness narratives, religion, and Catholicism. He has published several books, book chapters, and articles, mostly in Italian.

Liza McCoy is an associate professor of sociology at the University of Calgary in Alberta, Canada. Her research focuses on the social organization of knowledge and everyday practice in the areas of health, immigration, employment, and visual representation.

Michelle Miller-Day is an associate professor of communication arts and sciences, and bioethics and medical humanities at the Pennsylvania State University. She is the founding director of the Penn State Qualitative Research Interest Group, an interdisciplinary community of researchers involved in and supporting qualitative inquiry at Penn State University. Her research addresses human communication and health, including areas such as substance use prevention, suicide, and families and mental health. Her community-embedded research has involved numerous creative projects to translate research findings into social change. For the past 20 years, she has served as the principal qualitative methodologist for a National Institute on Drug Abuse line of research. This work has developed one of the most successful evidence-based substance use prevention programs in the United States and reaches youth in 43 countries worldwide.

David L. Morgan is a professor of sociology at Portland State University. He is a sociological social psychologist who specializes in focus groups and mixed methods. In addition to further developments in focus groups, his current scholarship is devoted to developing two-person interviews as a new format for qualitative interviewing.
Janice M. Morse is a professor and Presidential Endowed Chair at the University of Utah College of Nursing and Professor Emerita, University of Alberta, Canada. She was the founding director of the International Institute for Qualitative Methodology (IIQM, 1997-2007), University of Alberta and the founding editor of the International Journal of Qualitative Methods; since 1991, she has served as the founding editor for Qualitative Health Research. She is the recipient of the Episteme Award (Sigma Theta Tau) and honorary doctorates from the University of Newcastle, Australia, and Athabasca University, Canada. She was an inaugural inductee to the Researcher Hall of Fame (2010) and received the Lifetime Achievement Award, International Center for Qualitative Inquiry, 2011. She is the author of 420 articles and 19 books on qualitative research methods, suffering, comforting, and patient falls. Her most recent book (with Linda Niehaus) is Mixed Method Design: Principles and Procedures (2009).

Kirin Narayan is Professor of Anthropology at the University of Wisconsin-Madison. She is the author of Storytellers, Saints and Scoundrels: Folk Narrative in Hindu Religious Teaching (Pennsylvania, 1989), awarded the 1990 Victor Turner Prize for Ethnographic Writing from the American Anthropological Association and cowinner of the 1990 Elsie Clews Parsons Prize for Folklore from the American Folklore Society; Love, Stars and All That (Pocket Books, 1994), a novel; Mondays on the Dark Night of the Moon: Himalayan Foothill Folktales (Oxford, 1997), an ethnography composed around folktales retold by Urmila Devi Sood; My Family and Other Saints (Chicago, 2007), a family memoir; and Alive in the Writing: Crafting Ethnography in the Company of Chekhov (Chicago, 2012), a manual that offers ways to generate writing through examples and exercises.

Pirjo Nikander is a professor at the Institute for Advanced Social Research, University of Tampere, Finland, and adjunct professor at the University of Helsinki, Finland. She has studied institutional interaction, decision making in meetings, age in interaction, ageism, and moral discourse. Her publications include Age in Action: Membership Work and Stage of Life Categories in Talk (2002) and numerous chapters and articles on discourse analysis, age and ageism, membership categorization analysis, and 
transcription and translation. She has also coedited books on women and ageing, and the analysis of interviews.

Jennifer Platt is Emeritus Professor of Sociology at the University of Sussex, England. Her research interests are aspects of the logic and sociology of research methods, and the history of sociology. Her main publications include "Cases of Cases ... of Cases?" in What Is a Case? (edited by H. S. Becker \& C. Ragin); "Research Methods and the Second Chicago School" in A Second Chicago School? (edited by Gary A. Fine); A History of Sociological Research Methods in America, 1920-1960; The British Sociological Association: A Sociological History; and "Sociology" in The History of the Social Sciences Since 1945 (edited by Roger E. Backhouse and Philippe Fontaine). She has been concerned to extend the history of sociology beyond its traditional study of the thought of prominent theorists and so has also written on intellectual migration, the position of women in British sociology, and topics in the social system of sociology, such as editorial boards and presidential addresses. She is currently Vice President for Publications of the International Sociological Association and was for many years an officer of its Research Committee on the History of Sociology. In the past, she has been president of the British Sociological Association and editor of its journal Sociology; recently, she chaired the American Sociological Association's Section on the History of Sociology.

Jonathan Potter is Professor of Discourse Analysis and Dean of the School of Social, Political and Geographical Sciences at Loughborough University. He has worked on fundamental issues to do with the nature of human action and social science method. His most recent books include Representing Reality, which attempts to provide a systematic overview, integration, and critique of constructionist research in social psychology, postmodernism, rhetoric, and ethnomethodology, and Conversation and Cognition (with Hedwig te Molder), in which different researchers consider the implications of studies of interaction for understanding cognition. He is one of the founders of discursive psychology.

Tim Rapley is a staff scientist at the Institute of Health \& Society at Newcastle University, England. His current research interests are in empirical studies of medical work, knowledge, and practice, and social studies of research. He is the author of Doing Conversation, Discourse and Document Analysis (Sage, 2007), and recently, he wrote a chapter he is quite proud of, "Some Pragmatics of Data Analysis," for the third edition of David Silverman's (2010) edited collection Qualitative Research: Theory, Method \& Practice.

Catherine Kohler Riessman is a medical sociologist and Emerita Professor at Boston University. She is currently a research professor in the Sociology Department at Boston College. Her most recent book is Narrative Methods for the Human Sciences (Sage, 2008). Throughout her long career, she has studied and compared the narratives women and men develop to account for biographical disruptions, including divorce, infertility, and chronic illness in midlife. She has been the author of many journal articles and book chapters in recent years, and her early books include Divorce Talk (1990) and Narrative Analysis (1993). She has been awarded Leverhulme, British Academy, and Fulbright fellowships and has served as a visiting professor at the University of London, Victoria University in Melbourne, and the University of Western Sydney in Australia.

Carol Rivas undertakes research and teaching at Barts and the London School of Medicine and Dentistry, Queen Mary, University of London. She was previously based at St. Mary's Hospital, London. Before that she was a medical journalist, and she has undertaken commercial projects writing health communications and clinician training materials and developing telemedicine and multimedia educational resources. She currently lectures in medical sociology and teaches qualitative research methods to undergraduates and postgraduates. Her main research interests are in ethricity and culture, communication, and cognition. She has undertaken several studies on access to health care and its improvement, involving various approaches to data collection and analysis. She is particularly interested in encouraging other researchers to take up computer-assisted methods of video analysis. Her current projects are a video-based exploration of communication in medical consultations and development of an associated web-based multimedia educational and research resource.

Kathryn Roulston is an associate professor in the Qualitative Research Program in the Department of 
Lifelong Education, Administration, and Policy at the University of Georgia, where she teaches qualitative research methodology. Her research interests include qualitative research methods, qualitative interviewing, analyses of talk-in-interaction, topics in music education, and the preparation of qualitative researchers. She is the author of Reflective Interviewing: A Guide to Theory and Practice (2010) and has published articles and chapters on qualitative interviewing and analysis of interview data.

Timothy Rowlands received his PhD in 2009 from the faculty of Justice and Social Inquiry, School of Social Transformation, Arizona State University. His dissertation will be published in November 2011 on Video Game Worlds. Since his graduation, he has worked as research manager of a three-university longitudinal study of early infant and child care.

Anne Ryen is Associate Professor of Sociology and Vice Dean of the Faculty of Economics and Social Sciences at University of Agder, Norway. She is a former president of the European Sociological Association (ESA) Research Network on Qualitative Methods and present member of the ESA Executive Committee. Her research has focused on fringe benefits in private companies, cross-cultural research, and research ethics and the qualitative interview, and her publications include Verneverdig. Barnevern, forskning og metode (Child Care, Research, and Ethics, with Pal Repstad, 2001), Det kvalitative intervjuet: fra vitenskapsteori til feltarbeid (The Qualitative Interview: From Theory of Science to Fieldwork, 2002), and Hvordan kan frynsegoder bli belønning? (How Can Fringe Benefits Become Remuneration? with Knud Knudsen, 2005). In addition to writing articles and chapters in handbooks, she has been guest editor of journals such as Journal of Qualitative Social Work (2008), Qualitative Sociology Review (with Krzysztof Konecki, 2009), and International Journal of Social Research Methodology: Theory and Practice (with Giampietro Gobo, 2011).

Clive Seale is a professor of medical sociology in Barts and the London School of Medicine and Dentistry, Queen Mary, University of London. He is the editor of the journal Sociology of Health and Illness and author or editor of numerous books, including Con structing Death: The Sociology of Dying and Bereavement (Cambridge University Press, 1998) and The Quality of Qualitative Research (Sage, 1999). His edited methods textbook Researching Society and
Culture will be published in its third edition by Sage in 2012. He is interested in computer-assisted methods of text analysis using software developed for the discipline of corpus linguistics and carries out research using this and a variety of other methods. Currently, he is working with audio- and videotaped data to understand the communication issues involved in multilingual consultations in primary care in East London, where he now works.

David Shemmings is a professor of social work at the University of Kent, England, and a visiting professor of child protection research at Royal Holloway, University of London, England. He is currently the director of the Assessment of Disorganised Attachment and Maltreatment Project, which focuses on the detection and assessment of child abuse as well as how best to help families. Prior to moving to Kent, he was a professor of social work research at Middlesex University, England. He qualified in 1974 and worked with traumatized children for 5 years. He has spent the past 15 years undertaking research into attachment theory in close relationships. He has used Q methodology in the study of later life filial attachment and has presented papers in a number of international settings.

Royce A. Singleton Jr. is Professor Emeritus of Sociology at the College of the Holy Cross, where he taught for 32 years until his retirement in 2009. A quantitative researcher, he has conducted numerous surveys on a broad range of topics. His most recently published work, based on a series of campus surveys, addresses issues of student alcohol consumption and voluntarism. $\mathrm{He}$ is the coauthor, with Bruce Straits, of Approaches to Social Research (2010). He currently serves on the editorial board of Sociological Perspectives.

Bruce C. Straits is Professor Emeritus of Sociology at the University of California, Santa Barbara. His research areas include social demography, cigarette smoking and cessation, the social psychology of research settings, the influence of personal networks on individuals' attitudes and behavior, and research methodology. He is the coauthor, with Royce Singleton, of Social Research: Approaches and Fundamentals (Oxford University Press, 2011).

John B. Talmage is a professor of sociology at the University of Mobile. He has done research on homelessness and aging and has been involved in 
applied research. In addition to his academic career, he has been a business executive, a counsellor, and University Chaplain.

Carol Thomas is a professor of sociology at Lancaster University in the United Kingdom and is based in the School of Health and Medicine. She is currently director of the Centre for Disability Research at Lancaster University. She is best known for her publications in disability studies-including her books Female Forms: Experiencing and Understanding Disability (Open University Press, 1997) and Sociologies of Disability and Illness: Contested Ideas in Disability Studies and Medical Sociology (Palgrave Macmillan, 2007). She has also researched and published widely on the experiences of "patients" and "carers" of living with cancer and has recently completed a project funded by the Economic and Social Research Council (ESRC) on illness narratives in cancer contexts (ESRC project: RES-000-22-2031). Publications on narrative analysis have followed, notably in debate context in Volume 32, Issue 4 of Sociology of Health and Illness.

Jinjun Wang is a professor in the School of Foreign Languages at Yunnan University, People's Republic of China. She was a visiting scholar at the University of Sunderland, England, in 2005. Her academic interests include systemic functional linguistics, discourse analysis, sociolinguistics, and pragmatics. So far, she has published three books and nearly forty articles and has cotranslated three English-Chinese dictionaries. She has obtained seven research grants at the nation, province, and university levels. Now she is a vice director of the Foreign Languages and Literatures Research Institute of Yunnan University and acts as a directing member of the China Association of Functional Linguistics and the China Association of Comparative Studies of Chinese and English.

Carol A. B. Warren, Professor Emerita, taught at the University of Southern California for 17 years and the University of Kansas for 13, retiring in 2003. Her research interests over the years have included qualitative methods (ethnographic, historical, and interviewing), law and society, social control, gender, and the history of medicine and psychiatry. Her most recent books are Doing Qualitative Research, with Xavia Karner (2010) and Pushbutton Psychiatry: A Cultural History of Electroshock in America, with Timothy Kneeland (2008). Recent articles include "The Eyes Have It" (Ethnography, 2011), "Pride, Shame and Stigma in Private Spaces" (Ethnography, 2010), and "Interviewing Elderly Residents in Assisted Living," with Kristine N. Williams (Qualitative Sociology, 2008).

Ying Yan has research interests that include systemic functional linguistics and discourse analysis. She has explored metadiscourse in English movie reviews for her master's thesis. In 2009, she was chosen to study at the Yuan Ze University in Taiwan. Within a year's stay at the university, her excellence in academic research and university activities was appreciated by her teachers and colleagues. 